\title{
人胎児交感神経系の発生学的研究
}

\author{
日本医科大学解部学教室 (主任 横尾安夫教授) \\ 佐藤勤 \\ Tutomu Sato
}

\begin{abstract}
緒論
交感神経系は発生学的に媨脊髓神経節及神経管よ り，それらの最終の位置に移動する細胞から生ずる。 その組織発生に関する最初の観察は,1847 年 Remak の鵎胎児によるもので, 彼は交感神経采は中胚葉より 由来するとした。然し Balfour ('77) は鮫胎児による

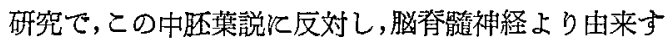
るという外肧葉説をたて, Schenk 及 Birdsall('78) ${ }^{1)}$ もこれ己同意見を発表した。次いで Onodi ('86) ${ }^{2)}$ 交感神経幹を構成する細胞は，脊瀡神経節の腹側端か ら Abschnürungsprodukt として生ずるとした。
\end{abstract} His, sen. ('90) ${ }^{3)}$ は $7 \mathrm{~mm}$ 長人胎児に於いて, 初め 飞交通枝が現れ，脊䐦神経節から細胞が交感神経幹汇 向つて移動するの権察し, His, jun. ('94) ') 鱒, 蛙, 鳥類及哺乳類胎児で, これら細胞の aktive Bewegung そいう説をたてた。Kohn ('05,'07) 児に於ける観察で, この Hisの説に反対し, 交感神経 幹を構成する細胞情髄神経節より由来するが，ての 細胞は脊喵神経の中で核分裂とよつて新しく增殖した るのであるとした。Froriep ('08) ${ }^{6)}$ 洁 Torpedo 及 鬼胎児に於ける観察で, 交感神経幹を構成する細胞は 神経管壁の腹半側部から由来するものであるとした。

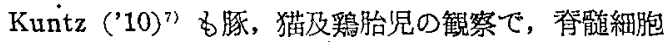
は神経管加ら前根及後根飞移動し, 前根に移動した綀

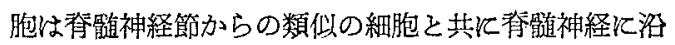
つて末梢に進み，それら細胞中のあるものは交通枝を 経て交感神経幹を生ずるとい 5，Froriep の説と本質 的に一致する意見を発表し，更に彼は鵎及蛙胎児によ る実験 $\left({ }^{\prime} 22\right)^{8)}$ て，㾞髄神経節及後根を除去しても， 交感神経幹及前登椎神経叢原基は前根を経て末梢に前 進する medullary origin の細胞から生じ, それらの 細胞は神経管壁の intermediate portion から由来す るという。又心藏,肺, 食道及胃に於ける神経叢 (Kuntz 梳 vagal sympathetic plexuses と名付けている) は，迷走神経を除去された胎児では交感神経幹及前脊 椎神経叢が存在していても生じない。即初め迷走神経
を経て由来した細胞から生し，後に交感神経幹からの

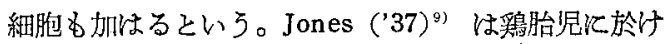
る実験で，神経㭚の除去された部分飞も交感神経幹が

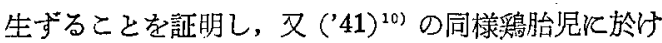
る実験で，交感神経節飞分化する細胞は神経管の腹側 部より由来することを証明した。内田('27) ${ }^{11)}$ は爬虫 類, 烏類及哺乳類胎児に於ける観察で, 心臓, 肺, 食 道及胃に於ける神経叢については Kuntz の観察と一 致するが，腸の神経叢は初め交感神経源の細胞より主 として生じ, 後に迷走神経源の細胞多受け入れるとい 5。骨盤神経基原基は Kuntz ('52) ${ }^{12)}$ とよると, 約 $12 \mathrm{~mm}$ 長人胎児で初めて現れ，乞れを構成する最初の 細胞は中枢神経杀より仙神経の内藏枝を経て由来し， 少し逴れて腹部の前脊椎神経叢からの細胞が加はると W5。

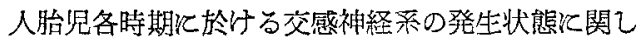

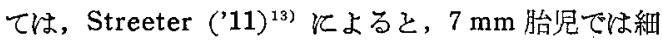
胞の遊走注完全飞進行し且二三の場所に細胞性の交通 枝が既存在して居り，9 $\mathrm{mm}$ 胎览で恔交感神経幹及 内葴神経の神経丵が明らかとなり，16mm 胎尘では末 梢の内臟神経節及頭部神経節は悉くその結合枝が認め られる程分化し，胎生 6 週の終り迄壮交感神経䒺の主 要部はすへて明膫になるという。父彼によると(08) 14)，10 mm 人胎昌で交感神経幹は輪漷のや」明ら かな連続せる細胞菜をなして，後頭部より下位仙椎の 高さまで，大動脈外僋，脊椎の前の位置飞ある。線維 形成は交感神経幹の全長にわたり認められ，殊に胸部 及下位頸部で最も渚明であるが，未だ分節構造にまで は進行していない。脊䯣神経前枝との交通枝は1万至 3 条の変動で各分節に見られるが，上位三分節ではこ れを欠如している。交感神経幹頭端は節状神経節と咽 頭壁との間の部分で, 舌下神経の内側にあり, 内钼動 脈に沿つたその延長及頭部神経節との連絡は見られな い。交感神経幹は第 6 より第11胸分節の高さの間て, その腹側方で fibro-cellular plexus が内缄神経及腹

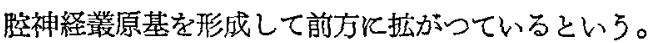


$-62-(1156)$

又 Streeter の諭文 ('05) ${ }^{15)}$ 中の插図で, $14.0 \mathrm{~mm}$ (5

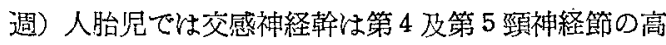
さで上頸神経節原基と思はれる膨大を示し，その頭端 は第 2 頸神経節の高さで節状神経節に近接して終り, 而神経との間に交通枝は描加れていない。又 $17.5 \mathrm{~mm}$

(6 週)人胎罗で恔交感神経幹江第 6 及第 7 頸神経節 の高さで細い線維束をなし，その上下で上及下頸神経 節原基を思はせる膨大を示し，との頭側端は内亞神経

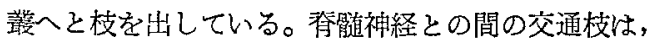
第 5,7 及 8 续神経並に第 1 胸神経との間に各 1 条宛 描かれている。Dickie ('14) ${ }^{16)}$ によると $20 \mathrm{~mm}$ 人胎 奣では，交感神経幹は頸部中央の高さで迷走神経の背 側に位置し;頭側に向つてはその外側に出て,舌咽神経 の外神経節の硝さで急に頸動腿に沿つて頭部に入る。 尾側间つて胸部に近ずくと迷走神経より離えるが 倍その背側火あり，第 7 頸襍の高さて鎖愲下綰を形成 するとい5。Kuntz (20) ${ }^{17)}$ は人胎児各時期飞於ける 交感神経系各部位の発生状態飞ついて比較的詳しく発 表している。即交感神経幹原基は約 $5 \mathrm{~mm}$ 人胎児で は，下位胸部より上位腹部で大動脈背外側面に沿つて 位置する小細胞群として発生し， $6 \mathrm{~mm}$ 人胎先では下 位頸部より仙部末でなり，弛い細胞集団の連続した 柱の形態をとる。この状態は 9 万至 $10 \mathrm{~mm}$ 飞達し， 交感神経幹原基が上位頸部より似部まで出現するま

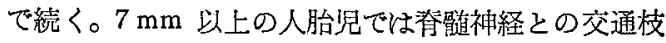
が胸部及腹部で交感神経幹に達している。10 $\mathrm{mm}$ 人 胎児になると交感神経幹の分節構造が明らかとなり始 め, 縦走する神経線維が出現する。 $15 \mathrm{~mm}$ 人胎児ては 頸部に於ける三分節も明蹽となり，頭端は内项動服に 沿つて神経線維として追求される。20 万至 $22 \mathrm{~mm}$ 人 胎児では交感神経幹の神経節は輸部明暸となり，それ らを互に連緦する神経線維束は殆んど細胞を伴つてい ないといる。

前脊椎神経丵 (prevertebral plexuses) の発生に関 しては, Kuntz によると $6 \mathrm{~mm}$ 人胎児では上腹部に 於いて，交感神経幹から少数の細胞が大動脈の側面に 向つて追求され，それよりや」発生の進えだ胎児では， この前脊椎神経叢飞第 4 㕛注第 5 胸分節以下の胸部交 感神経幹から出た線維が入り，又脊髄神経之の交通枝 から分れた枝が交感神経翰を経ずに直接入る。9 万至 $10 \mathrm{~mm}$ 人胎児では腹大動服の腹側及腹外側面の細胞 集団はかなりの大きさとなり，その一部の細胞は腎動 㟲に沿つて副篎原基に移動するという。

副腎と交感神経系との発生学的関係については,
Wieman $(20)^{18)}$, Hett ('25) ${ }^{19)}$ 及 Kohno $(25)^{20)}$ 等 の論文中に見られる。即Wieman によると $9 \mathrm{~mm}$ 人 胎児ては副婜は未だ明らかな器官として認められず， 脊梿神経の交通枝よりの線維が交感神経幹に入らない で腹唄へと延びている。12 mm 人胎児では副腎は輪 廓が朋瞭となり，その中央側に密接して線維束と神経 節の集団があり，副腎腹側境界近くで若干の神経組織 が副㹂契内質内進入している。交感神経幹の神経節か ら直接腹側へと神経束が延び，その末梢部に神経細胞 群が見られ，これらは腹腔及內臓神経基原基と思はれ る。㕛脊骾神経との交通枝には $9 \mathrm{~mm}$ 例で見られた 様な分枝無いという。Hett('25) によると $12.2 \mathrm{~mm}$ 人胎児では交感神経幹より腹側に向つて前進する細胞 が見られるが，その皮質原基内党の進入は誌められな 认。 $15 \mathrm{~mm}$ 人胎児です同様の状態で, $19.6 \mathrm{~mm}$ 人胎

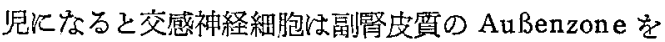
越えて，その Innerezone そ搪がる。大動脤周囲の細 胞群は未だ神経節細胞及 Paraganglien に分化してい ない。 $20.3 \mathrm{~mm}$ 人胎巟で注皮貿原基内へ細胞が蔡状 をなして進入して居るていう。

心缄神経叢の発生に関しては, His, jun. ('92) に よると胎生 4 週末の人胎胃では, 肺動脤と大動服との 間隙で迷走神経，反回神経及交感神経幹等よりの枝で。

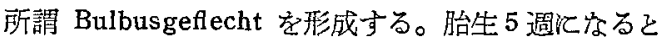
心房の下面, 即心囊膜の移行部により被はれた部分で Vorhofplexus を形成し, 次いて心翼膜の Sinus transversus の後方, 従つて心囊膜外飞 Verbindungsgeflecht を生ずるという。

Schenk 及 Birdsall ('78) Kよると, $22 \mathrm{~mm}$ 人胎 児で交感神経性の節状の細胞集団を腸管にまで追求 乙,腸管上部腈囲の紐胞集団は Plexus Auerbachii 原 基となるという。His，jun. ('97) 21) の腹部交感神経 の発生に関する論交によれば, $10.2 \mathrm{~mm}$ 人胎児て既に 成人に於ける状態の基礎が出来上つているという。即 腹腔神経丵, 内茂神経, 骨盤神経節, 腹大動豚神経凿

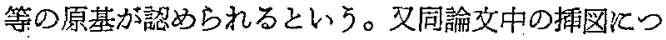
いて見ると, $9.1 \mathrm{~mm}$ 人胎児で右側交感神経幹から然 門附近の罢壁に向つて細胞の遊走を示している。

頭部交感性神経節の発生に関しては，Kuntz (20) の調查によると毛様神経節に関する研究を除いては不 完全な報告に止まつている。

毛様神経節原基は Carpenter ('06) とよると, 鵎胎 呪で浪初動眼神経を経て中脳から移勘した細胞から 生じ，その後の発生で眼神経を経て半月状神経節から 
移動した細胞が加いるとい。然し Broman('11) 及 Streeter (12) は人胎児不於ける観祭で, 動眼神経を 経て毛様神経節に入る細胞を諗めることが出来ず, 専 ら半月状神経節からの細胞加ら告ずるとした。Ganfini ('17)によると種々の脊椎動物殊に晡乳類胎児では, 明 らか動眼神経と眼神経の雨方が発生的関係がある とい5。Kuntz ('20) の人胎児仿ける観察でも, こ の Carpenter 及 Ganfini の説洞意している。即 $14 \mathrm{~mm}$ 人胎児では眼神経から動眼神経へと延びる連 続した細胞集団をなしているという。Dixon('96) ${ }^{22)}$ も $6.9,9.1,13.6,17.5 \mathrm{~mm}$ 及 8 週人胎尛於ける観 察で, 毛様神経節は $13.6 \mathrm{~mm}$ 例で細胞集団として初 めて明らか誌められるという。

翼口篮神経節の発生に関しては, Kuntz によると $11 \mathrm{~mm}$ 人胎児で初めて大浅岩神経の生長端に, 滕神経 節から移動した細胞集団として生し，上䫴神経内側に 位置するがこれとの連絡は未だない。12 万至 $15 \mathrm{~mm}$ 人胎皃では上顎神経の枝に治つて半月状神経節からの 細胞が連続し，ての生長端に細胞集団を形成する。 $15 \mathrm{~mm}$ 万至 $21 \mathrm{~mm}$ 人胎皃では上顎神経から多数の 細胞を伴つた線維性の枝が翼口蓄神経原基へと趠びて いる。以上の所見より彼は，翼口蓋神経節は一部は大 浅岩神経を経て沝神経節から移動した細胞で，大部分 は上顎神経及乞の枝を経て半月状神経節から移動した 細胞から生ずるという。

耳神経節の発生に関しては, Kuntzによると 7 乃至 $8 \mathrm{~mm}$ 人胎尖で舌胭神経の外神経節から出る鼓室神 経は，多数の細胞を佯つた細い枝で， $7.85 \mathrm{~mm}$ 人胎児 失状切片でこの枝は膝神経節近くまで追求される。 $10 \mathrm{~mm}$ 人䑚㸺では鼓室神経は膝神経節よりの線維と連 絡し，小浅岩神経は半月状神経節の少し下方まで追求 され，そこで細胞の小集団が見られる。 $13 \mathrm{~mm}$ 人胎

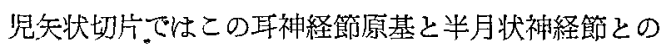
間飞細胞性の連絡がある。 $14.5 \mathrm{~mm}$ 人胎児では下顎 神経から線維性の枝が耳神経節原基に向つて延びてい る。 20 及 $21 \mathrm{~mm}$ 人胎児でも耳神経節原基江入る下 顎神経の枝は末だ細胞を伴つている。以上の所見より 彼は，耳神経節柱初力小浅岩神経の生長端飞於て外神 経節より移動した細胞より生じるが，この神経節を構 成する大部分の細胞は半月状神経節及三文神経の運動 根から由来するとい 万。㞋 $14 \mathrm{~mm}$ 上り $21 \mathrm{~mm}$ まで の人胎児ては, 耳神経節と翼口蓋神経節とは互に細胞 条で連絡しているが, それ以上の胎児では見られなく なるという。
顎下神経節の発生に関しては, Kuntzによると未だ 翼口培神経節及耳神経節が単に痕跡として認められる 10 万至 $11 \mathrm{~mm}$ 人胎児で,既てかなりな大さの緗胞集 団として, 下䜾神経の舌神経の経過中炕罗られ, 豉索 神経は未だ舌神経㒓していない。12mm 以上の人胎 児では，この細胞集団は舌神経を完全に取囲んている。 以上の所見より彼は，颚下神経節は初め舌神経を経て 末梢に移動する三弪神経源の細胞から生し, 後に鼓索 神経によつて顔面神経源の細胞が加はるといら。

舌下神経節の発生に関しては，Kuntz によると 12 $\mathrm{mm}$ 以上の人胎児では，細胞を伴つた舌神経心頻下神 経節原基を越えて末梢に延び，そこで小細胞集団を形 成して舌下神経節原基となるといら。

以上人胎児を主とする交感神経系の発生朔する関す 要な文献について記載したが，これらを見るに，Streeter ('08) の.10 mm 人胎児飞於ける末梢神経系汇

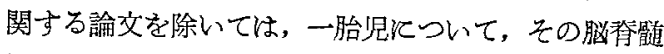
神経の発生状熊と交感神経系の発生状態とを併也記載 しているるのが誌められない。著者はこの点に主眼を 置きつょ，各時期の胎児で交感神経系の発生状態を先 人の所見と比較検討した。

材料横昆教授所蔵の $7 \mathrm{~mm}, 6 \mathrm{~mm}(\mathrm{~K}), 10 \mathrm{~mm}(\mathrm{a})$, $14 \mathrm{~mm}(\mathrm{~K}), 13 \mathrm{~mm}$ (a) 及 $20 \mathrm{~mm}$ 人胎児で, 何れる $20 \mu$ の厚さの連続切片で, Haematoxylin-Eosin 染色 のるのである。

\section{所 見}

1) $7 \mathrm{~mm}$ 人胎児（附図参照，図 1)

神経管は完全に閉鎖。脊煘道の横断面は既にエペンデ イユウム層, マント居及周辺首の三層に分れているが, マント首及周辺層は未だ溥い。脊㗓神経節は 31 対。 頭神経附属の神経節す，三文神経から副神経まで皆存 在する。

脳髄は終脳では大脳半球の膨出が始まつているが末 だ明らかでない。臭板は肥厚しているが，陷山は見ら れない。間脳から左右炕広い管腔を的つて突出する眼 杯原基は，半球形をなし，上皮から半球形你四した 水晶体窝をとり囲んで居り，その色素首には色素顆粒 殆んど欠如している。水晶体茼は未だ上皮加らくび れる様子は見られない。間脳底には未だ漏斗の突起は 生じていない。以上の所見より，この胎児は Streeter

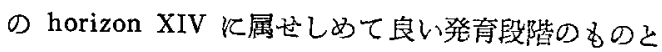
思われる。

交感神経午原基は上頸部より下胸部にわたり, 背側 大動脈及下行大動脈の背外側面に沿つて散在する少数 
の神経細胞群として見られ，その輪驻は未だ不明膫で， 上下の連絡は未だ連続的ではなく, 大体脊喣神経節沉 対応する細胞集団がとぎれとぎれに続いて居り，線維 はその全長代わたり何処ても未㒛められない。艾感 神経幹頭端は頸動服に沿心て終り， $\mathrm{C}_{5}$ 及 $\mathrm{C}_{6}$ の高さ で稍: 多数の紐胞が集団をなし，上頚神経節原基を形 成し始めている様江思われる。両側とす $\mathrm{C}_{6}$ 尾側の高 さで䀣江鎖骨下綰原基を思わ甘る細胞の配列を示して いる。脊嗵神経腹側枝は多数の細胞を伴つて居り,こ れと交感神経幹との閻に緗胞性交通枝が,左㑡で $\mathrm{C}_{1}$ より $\mathrm{D}_{5}$ まで，右側では $\mathrm{C}_{1}$ より $\mathrm{D}_{10}$ までの間で 1 乃至 2 条の変動で見られる。それらの内, 両側己も $D_{1}$ 以下では, 脊跣神経腹側枝加交感神経翰炕向つ て細狍を伴つた線維が出ているが，直ぐ消失して， 交感神経幹まで達していない。前脊椎神経叢原基と思 はれるもの洁認められない。文頭部には未だ交感性の 神経節は見ら礼学い。

2) $6 \mathrm{~mm}(\mathrm{~K})$ 人胎児

神経管は完全汇閉鎖。脊能道の横断面はエペンディユ ウム周，マント層及周辺㬝の三層汇分れ， $7 \mathrm{~mm}$ 例と 同様汇矢張り間辺層は未だ薄いが，マント首は腹㑡寄 りではその厚さを增している。脊噵神経節は 32 対, 頭神経附属の神経節も, 三叉神経から副神経まで皆存 在する。

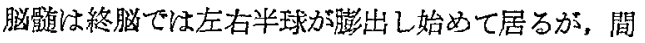
脳との境界は未だ不明膫である。搝板は陷四が始まつ ている。間脳より左右化乫出する眼杯县は, 管腔は未 だ広いが，水晶体小胞は上皮より全く落ち迄んで，表 面炕開孔は見られなくなつている。眼杯の色素首炕は

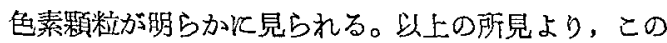
胎览は Streeter の horizon XV 江属せしめて良い発 育段階のものと思はれる。

交感神経幹原基は上頸部上り上腰部飞わてつて現 れ, これ構成する細胞の数す $7 \mathrm{~mm}$ 例上り多くな り，上下の連絡も大体連続的となり，去の中多少の 線維が見られるが，少輪廓は不明瞭で，分節構造は未

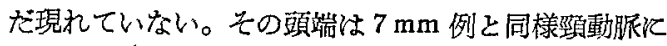

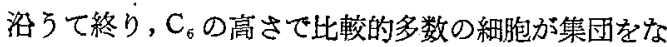
乙て, 上頸神経節原基を形成し，その尾側 $\mathrm{C}_{7}$ の高さ で鎖骨下綰原基を思わ就胞の配列を示す。脊哊道神 経腹側枝々交感神経幹との間の交通枝は， C までは幾分不明膫な所るあるが，大体細胞性交通枝が 見られ， $\mathrm{C}_{8}$ より $\mathrm{L}_{1}$ までは線維性の交通枝が見られ る。これら腹側枝及交通枝は何れも細胞を伴つてい
る。胸神経節 $\mathrm{D}_{1}$ 乃至 $\mathrm{D}$ 、にわたり, 交感神経幹から 腹側方人，下行大動服の左右耐側行小さい細胞集団方 多少途だえながら延びて行つて居るが，左右のるのは 大動㟲の腹側で連繶与るに至らない。この細胞集団に， 春䯣神経腹側枝から出る交通枝の分枝が，交感神経幹 を経ず值接入るところが 5 万至 6 ケ所にある。恐ら

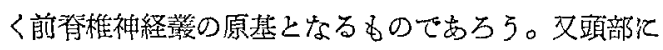
は $7 \mathrm{~mm}$ 例同樣交感性の神経節恃未元見られない。

3） $10 \mathrm{~mm}$ (a) 人胎児（附図参照，図 2)

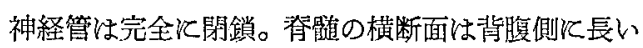
棈円形をなし，令の左右両側壁な曆く，背腹側壁な薄

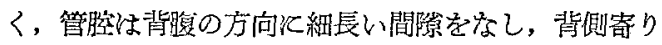
の部分が左右炕应大している。左右両側壁は三尿即ち

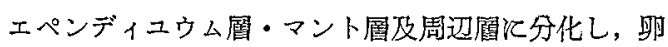
円形線維束が諗められる。脊梿神経節は左側 32 侗,

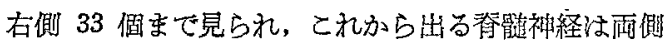

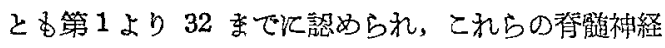
は全て未だその中細胞伴つている。頭神経附属の 神経節る，三神綴から副神経まで皆存在する。

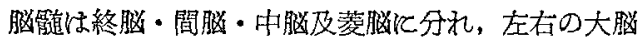
半球膨出し，その膨出の間脳とのつぶきてはくびれが 見られる。原始鼻腔は既飞胭頭に向つて開孔し, 鼻腔 に対する終脳壁は稍 突出する眼杯原基は, 内腔は既江消失し始め, 色素層

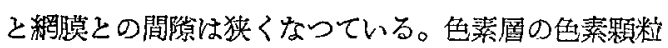

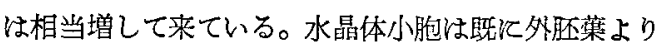
独立し，关の梁側の細胞の形がかなり長くなってい る。間膊中央部から下方へのびる漏斗の細長い突起を

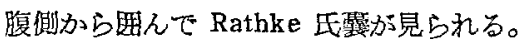

滑車神释は既に発生し，淩脳峽上壁より出で，その 脑壁中に神経交义も認められ，中脳の外側を腹側江向

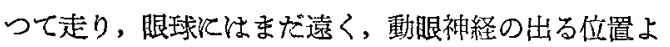
り余り遠くないところで消失している。

動眼神経は眼球後方下部の細胞密集部で分椟して終 クこの神経の起始には多少の細胞を交へているが， 全経過江沿うて毛样神経節原基を考えさせる細胞集団 はまだ認められない。

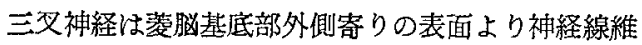
を僅かに混じた細胞集団として始まり，直ちに半月状 神経節原基をなす，周囲との境界のまだ不明瞭な大き な緗胞集団となり，その内側とは Portio minor の線 維束がある。半月状神経節より出る眼・上颚及下顎の 各神経は, 何れもその起始部の中多数の細胞を伴つ ている。眼神経は前主静脈外側を経て頭側え向い，眼 
球の後方を上行しつ」左側では 1 枝を分ち，右側では 分枝は見られず，更に眼球上方へ彎曲しつ」両側とも ”枝分れて終る。その経過中毛様神経節原基を思わ

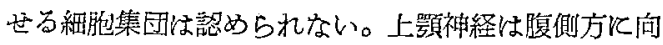
い，多数の分束となつて上顎突起中で分散して終り， その各分束の末端化附属神経節と考えられる細胞集 団は諗好られない。下頕神経は背側向いつ小尾側に 下り，分枝することなく終る。气の経過中耳神経節及 频下神経節原基を思わせる細胞䈎団は見られない。

外旋神経江眼球後方下部の細胞密集部にて 2 枝に分 れて終る。その位置は㗢眼神経終末部の尾侧方である。

顔面神経性楚神経節と，鼓索及大浅岩神経等の分枝

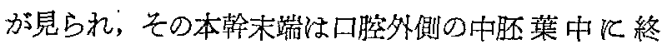

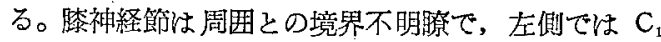
尾側端・右側で $\mathrm{C}_{1}$ 中央の高さて筷神経節尾側端上 り出万大浅岩神経怔, 内頸動脈外側接して直ち飞消 失し, 上敫神経加らは遠く終つている。耐側とも $\mathrm{C}_{2}$ 中央の高さで顔面神経より出垵荣神経は，下顎神経 に較ベて一㒸のびて居り，下顎神経末端からは薏く離 れて経過し，舌根部外側で終る。

聴平衡神経化属する神経節及びこれから耳胞壁汇達 する若下の末梢神経が諗められる。

舌咽神経は頭蓋内及外神経節の区別を生し，頭蔁外 神経節尾側端から $\mathrm{C}_{2}$ 頭側端の高さで出る1枝注, 非

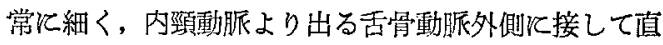
ちに消失し，これは鼓室神経となるものと思われる。

迷走神経で约既に魄神経節及節状神経節が区別さ れ，上所頭神経及反回神経の分枝韶められる。本幹 は食道と気管との間の直ぐ両外側沿つて下降し, 肺 原基枝を出した後，胃の部分で終る。

副神経の脊鹃部は $\mathrm{C}_{2}$ の高さまで追求出来る。

舌下神経恃左右とも 3 個の神経束を形成して腹尾側 方へ走り，次第に 1 条の神経束となつて迷走神経背側 飞接し，第 1 及 2 頸神経腹側枝と吻合する。下行枝は $\mathrm{C}_{4}$ の高さで第 1,2 及 3 项神経腹㑡枝と吻合して舌下 神経綰を作る。

交感神経幹原基は上位頸部より腰部までの高さの間 で, 周囲との境界の末だ明膫でない細胞集団の杜とし て誌められ，仙部の高さ以下ではその輪遊が次第に不 明膫となつている。節状の明らかでない部分するる が，下位胸部以下腰部までは比較的明膫であるが，そ れらを連絡する細胞条にはな神経線維が少い。交感 神経幹は両僋とも $\mathrm{C}_{5}$ 及 $\mathrm{C}_{6}$ の高さでまだ有対の状態 の下行大動脤の内背側, 脊椎原基の腹外側で著しく膨
大して上頚神経節原基を形成し，との横断面は综心゙円 形をなし，紐胞の密集状態が見られる。

上頸神経節頭側は両側とも $\mathrm{C}_{3}$ 中央の高さで内项㑔 服背側よりその内外側を囲む細胞群をなし，これは内

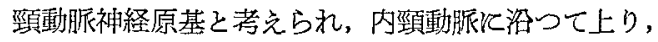
左側は $\mathrm{C}_{2}$ 頭側端，右側々 $\mathrm{C}_{2}$ 中央の高さで内帺動䐂 背側, 節状神経節内側化接して終る。両㑡とも内頸動 脈淁する高さで節状神経節尾側端との間江 1 条の細 胞条が認められる。

上頸神経節は尾側飞向 5 飞従つて脊椎原基の腹外側 面飞近づき，両側とも $\mathrm{C}_{7}$ の高さで夫々左右鎖骨下動 脈が神経幹原基内を通り，鎖骨下綰を形成している。

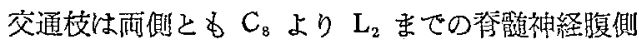
枝と交感神経幹との間に 1 乃至 2 条の変動で見られ，

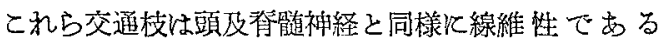
が，向緗胞を伴つている。份顽側方 $\mathrm{C}_{2}$ より $\mathrm{C}_{6}$ まで

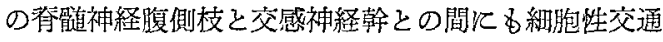
枝を思わせる所見が認められる。即，この再者間腹 側枝内に見られる細胞, 且文交感神経幹を構成する細 胞と同様の大さ，同様に淟染せる核を有する細胞が多 数㳻在して見られる。

副腎皮質原基は $\mathrm{D}_{1}$ より $\mathrm{D}_{6}$ までの高さの閐で，腹 大動脈の雨側自られ，その横断面は長徍を ventromedial から dorsolateral へ向けた略く棈円形をな し，周囲との境界はすだ不明膫である。左側は $\mathrm{D}_{2}$ よ り $\mathrm{D}_{4}$, 右側仙 $\mathrm{D}_{3}$ 上り $\mathrm{D}_{4}$ の高さの間尔, その背僋 で支感神経幹と接する。副謷内側と単一の腹大動㟲と の間前脊椎神経裳原基をなす細胞群が, 両側とも $\mathrm{D}_{2}$ より $D_{6}$ の高さの間で認められ，左側では $D_{3}$ より $\mathrm{D}_{7}$, 右側では $\mathrm{D}_{2}$ より $\mathrm{D}_{7}$ の交通枝加分れた神経線 維束が交感神経幹を経ずに滑接これに入る。この高さ の部分の交感神経幹腹側境界は不明瞭で, 前冾椎神経 裳化移行する。副腎髄質細胞及その副腎皮質内への侵 入はまだ涊められない。

$\mathrm{D}_{6}$ より $\mathrm{D}_{9}$ の高さの間で腹大動脈は，その雨側上 り腹側とかけて交感神経幹を構成する細胞と同様の多 様の細胞群比よつて团まれ，腹腔神経叢原基をなし， 左側では $\mathrm{D}_{8}$ より $\mathrm{D}_{11}$, 右側では $\mathrm{D}_{7}$ より $\mathrm{D}_{10}$ の交通 枝から分れた枝がこれに入る。又交感神経幹腹側と此 の神経叢との境界は大体明らかであるが，向明らかで ない所子見られる。

4) $14 \mathrm{~mm}(\mathrm{~K})$ 人胎児 (附図参照, 図 3 )

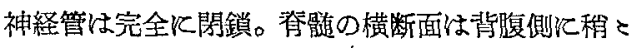
長い棈円形をなし，管腔は背腹の方向細長く，背側 
㟢りの部分が少しく左右汇拡がり, 境界溝炕よつて翼 状板々基底板分けられる。管腔の両側は 3 屖即ちエ ペンディユウム・マント及周辺層化分化し，翼状板外

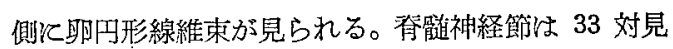
られ，これらから出る脊融神経は左側は第 1 より 32 ， 右儧は第 1 上り 31 まで認められる。頭神経附属の 神経節も三经神経から副神経まで皆存在する。

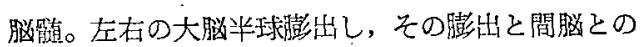
つづきにくびれが見られる。原始畫腔は既に咽頭に向 つて開口し，舅腔と終脳壁との間の中肧葉層には神経 細胞集団が热められる。間脳から左右以乫出する眼杯 原基は，内腔蔇に消失し，10 mm(a) 所見と余り変ら ない。視床原基をなす間脳壁の肥厚は相当厚くなつて いる。視床下部から突出する漏斗及びこれを腹側から 因むRathke 氏覀も見られる。

滑車神経は菱脳陝上壁より出るが，この位置沉来る 神経交叉る明膫飞見られ，中脳外側を腹側飞向い，動 眼神経外側, 前主静脈外側を経て頭側に上り, 分枝し て眼神経と吻合した後, 眼球下方よりにて後方の細胞 密集部て終る。

動眼神経は終脳外側, 半月状神経節内側に接与る前 主静㟲の内側近くを走り，腿球後方下部の細胞密集部 で，滑車神経終末部より少しく頭側よりの高さで分枝 して終り，滑車神経との物合は明らかでない。その経 過中毛㥞神経節原基を思わせる紐胞集団は認められな w。

外旋神経は動眼神経の下方を経て, 眼球後方下部の 細肘密集部で, 滑車及動眼神経終末部の中間の高さで 分枝じて終り，これらとの吻合は明らかでない。

三文神経。半月状神経節原基は周囲との境界比軦的 明睽な大紐胞集団をなし，その内㑡と神経線維束より なる Portio minor が見られる。

眼神経は眼球後方を頭側似上り, 眼杯の眼蕉移行部 上方附近に短小の 1 枝を出した後, 眼球上部にて分枝 して直ちと終る。その経過中毛様神経節原基を思わせ る細胞集団は見られない。

上颚神経梳多数の分束として半月状神経節より出 て, 主として上碞突起の部分で分散して終り，一部は 原始鼾腔の咽頭開口部背外側で, 刃その一部は尾側と 向い，翼口蓋神経節原基と考兄られる疎らと散在する 神経細胞群中に終る。

下顎神経恬, 煩及下画槽神経等分れれ, 舌神経は 鼓索神経と舌根部外側で, 左側て法 $\mathrm{C}_{1}$ 頭側端, 右側 では $\mathrm{C}_{1}$ 頭側端より約· $280 \mu$ 頭側よりの高さで吻合
し，その雕囲主として内側よりと哿下神経節原基と思 われる節状をなす細胞集団が見られる。又とれより末 梢舌内部々舌下神経節原基と思われる小細胞群が数ケ 所飞認められる。右側は下融神経が半月状神経節より 出る高さ, 左側はそれより少しく覒側の高さより下方 そかけて, 下顎神経の内背側近くに蹯沉散在する神経 細胞㲔が見られる。これは耳神経節原基と思われる がとれと下顎神経との間の吻合は明らかでない。

顔面神経。膝神経節は未だ発育不充分で, 神経細胞 わ少い。C $\mathrm{C}_{1}$ 頭側端より左側で約 $540 \mu$, 右側ては約 $840 \mu$ 頭側よりの高さで膝神経節より出た大浅岩神経. は, 内頸動腿内側飞接した後, 咽頭外㑡部て散在する 翼口蓋神経節と思われる細胞群中飞終る。鼓索神経仙 左側は $\mathrm{C}_{1}$ 頭側, 右側は $\mathrm{C}_{1}$ 頭側端より約 $160 \mu$ 頭側 よりの高さで顔面神経より出て頭側と向い, 舌根部外 側で左側は $\mathrm{C}_{1}$ 頭側端,右側は $\mathrm{C}_{1}$ 頭㒋端より約 $280 \mu$ 頭側よりの高さで舌神経と吻合する。佮吻合する少し 〈手前より鼓索神経の周囲比顎下神経節を形成する細 胞と同様の細胞群が認められ, この細胞群は顎下神経 節原基潈く。顔面神経の本幹は口腔外腹側の中罘葉 中分散して終る。

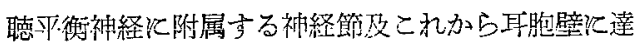
する神経束が見られる。

舌咽神経山頭蓋内及外神経節完全江分離し, 外神経 節は左側は $C_{1}$ 頭側端, 右側は $\mathrm{C}_{1}$ 頭側端より約 $300 \mu$ 頭側の高さとあり，両側とも气の尾側端腹側より出た 1 枝は鼓室神経原基と考方占れ, 咽頭向以つ小a及 bの 2 枝江分れ，a 枝は内㲁動脈より舌骨動脈が出る 高さで内頸動脤外側淁し, 外神経節頭側端より出る 1 枝と吻合した後, 左側は内頸動脈外側を頭側宁い つふ小細胞群炝つよ゙き，これょり離れて再び b 枝と合 して 1 条となり, 右側で恬骨動㟲内側㢺しつょそ こて小細胞群炡つがいた後, これより離れて再びb枝 と合して 1 条々なり，何れる咽頭の背側を傊方, 顔面 神経光と向い，大浅岩神経が出る高さで滕神経節とを の腹側て吻合し，反転して耳神経節原基に背側より入 る。これは小浅岩神経原基と思われる。舌咽神経の本 幹の末端は舌中にて終る。

迷走神経。頸神経節及節状神経節は完全飞分離し, 上喉頭神経及反回神経子発育している。乞の本幹は食 道と気管との間の外側を下降し, 肺原基枝を出した 後, 胃の部分で終る。

副神経の脊檤部ね $\mathrm{C}_{6}$ の高さをで追求出来る。 舌下神経は左右とも 3 個の神経束となつて腹尾側方 
え走り，3束中の最頭側の1束は他と比して細い。と の 3 束は次第飞 1 条の神経束に合して節状神経節背側 飞接し，第 1 及 2 形神释腹僋枝々吻合する。下行枝は $\mathrm{C}_{4}$ の高さで,内頸静腿背外側部で第 2 及 3 栭神経腹側 枝と吻合して舌下神経綰を作る。本幹は迷走神経化接 しつ小羬側よりその外側を迴つて腹側て移り, 迷走神

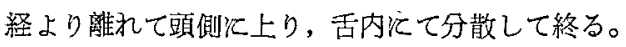

交感神経幹原基は上位頸部より仙部にわたつて見ら れ，周囲との境界明膫で概る節状をなしているるが，上 位胸部ではや小不明膫, 且つ各節間を捙絡する神経線 維束は，全く線維性のところる現われているが，まだ 神経細胞を伴つているところが多い。交感細胞幹は左 側は $\mathrm{C}_{4}$ より $\mathrm{C}_{6}$, 右側は $\mathrm{C}_{3}$ より $\mathrm{C}_{5}$ の高さの間で 膨大して上频神経節原基を形成し，多数の神経絧胞の 密集が見られる。両側とも $\mathrm{C}_{2}$ 及 $\mathrm{C}_{3}$ の高さで節状神 経節内側江密接している。(以下插図 1 参照)。

左側上頸神経節頭側は $\mathrm{C}_{2}$ の高さで $\mathrm{a}, \mathrm{b}, \mathrm{c}$ 及 $\mathrm{d}$ の

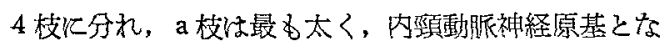
つて内頸動脈背側化接して上り， $\mathrm{C}_{1}$ 中央の高さで $\mathrm{a}_{1}$

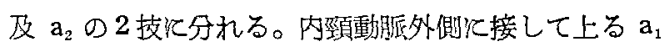
枝は, 内頸動腿上り舌骨動脈が出る高さで舌咽神経の 頭蓋外神経節を吻合した後, 大浅岩神経とす吻合して 終る。内側淁して上る $a_{2}$ 枝は， $a_{1}$ 枝が終る高さよ り少しく尾側て内頸動脈内側に接して終る。b枝は $\mathrm{a}$ 枝の背側近くを頭側们向い， $\mathrm{C}_{1}$ と $\mathrm{C}_{2}$ との境の高さ で、枝背側近づきつ小消失し，吻合は明らかでな

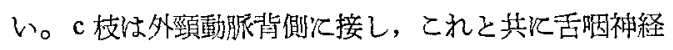
飞近づき，頭蓋外神経節尾側端と吻合する。d 枝は $\mathrm{C}_{1}$ そ $\mathrm{C}_{2}$ との境の高さで更に $\mathrm{d}_{1}$ 及 $\mathrm{d}_{2}$ の 2 枝に分 れ, $d_{1}$ 枝は頭蓋外神経節尾側端之吻合し, $\mathrm{d}_{2}$ 枝は第 1 頸神経腹側枝々吻合した後, 節状神経節頭側端内側 近くで小細胞粼につがいて終り, これとの吻合は明ら かでない。左側上頸神経節はさらに尾側方 $\mathrm{C}_{3}$ 攻 $\mathrm{C}_{5}$ の高さで夫々 2 枝点出し，乙れらは互㽗合して $\mathrm{C}_{5}$ 尾側の高さで 1 条となり， $\mathrm{C}_{6}$ 頭側の高さで大動脈外 側て小細胞群沉つぶいて終る。又 $\mathrm{C}_{6}$ の高さで3枝を 出し, 1 枝は第 5 形神経腹側枝々吻合し，1枝は頭側 に上り $\mathrm{C}_{5}$ と $\mathrm{C}_{6}$ との境の高さで大動脈背側で小緗胞

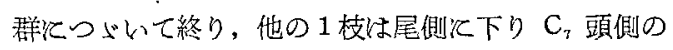
高さて大動脈腹側で小細胞群化つぶいて終る。

右側上頸神経節頭側ね $\mathrm{C}_{1}$ 尾側及 $\mathrm{C}_{2}$ 頭側の高さで

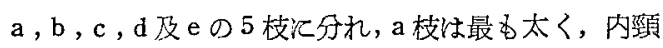

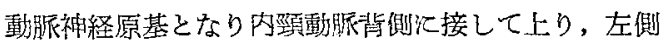
より少しく頭側の高さで $a_{1}$ 及 $a_{2}$ の 2 枝沉分れる。
内熼動脈外側炕接して上る $\mathrm{a}_{1}$ 枝怙左側と同様, 内頸 動脈より舌骨動脈が出る高さで頭蓋外神経節と吻合し た後, 更に上つて大浅岩神経と吻合して終る。内側飞 接して上る $a_{2}$ 枝は， $a_{1}$ 枝が終る高さより少しく尾側 で内頸動脈内側江接して終る。b挍も左側と同様 $\mathrm{a}$ 枝 背側近くを頭側と上り， $C_{1}$ 頭側端の高さで $\mathrm{a}$ 枝背側牧 近づきつ小消失し，吻合は明らかでない。c枝も左側

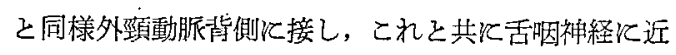
づき, 頭蓋外神経節尾側端々吻合する。 $\mathrm{d}$ 枝は $\mathrm{C}_{2}$ 頭 側の高さで舌咽神経と吻合する。e 枝恃左側 $d_{2}$ 枝を 同㥞節状神経節頭側端内側近くで小細胞群汇つぶいて 終り，これとの吻合は明らかでな。右側上頸神経節 はさらに尾側方 $\mathrm{C}_{3}$ 中央の高さで1枝を出し，これは 第 2 殁神経腹側枝と舌下神経とが合したものと吻合す る。 $\mathrm{C}_{4}$ の高さで出た 2 枝は迷走神経と吻合する。及 $\mathrm{C}_{5}$ の高さで 2 枝を出し, 第 5 顽神経腹側枝之吻合す る。

上頸神経節は禹側とも $\mathrm{C}_{2}$ 及 $\mathrm{C}_{3}$ の高さては節状神 経節内側汇密接し，それより，尾側江向つては，節状神 経節婂しつ」その内側より内背側洺り， $\mathrm{C}_{3}$ 尾側の 高さでこれより離れ，食道原基の両側を程て脊惟原基 の腹外㑡面近づく。 $\mathrm{C}_{6}$ と $\mathrm{C}_{7}$ との境の高さで細くく びれて神経線維束となり， $\mathrm{C}_{7}$ の高さで前後の 2 枝て分 れ，鎖骨下䊒原基となり，その間消鎖骨下動脈を包み， 再び前後枝は合し， $\mathrm{C}_{8}$ の高さで膨大し多数の細胞密集 して下頸神経節原基を形成する。鎖骨下綰は，右側で は後枝は非常に細く, 前枝は太いが, 左側ては殆んど 同じ太さで, 後枝の方がや」太くなつている。右側鎖 骨下綰頭側端で, その背側上頭側们向つて1枝を出し， $\mathrm{C}_{6}$ の高さで交感神経幹背側近くで消失する。此の枝 そ第 6 形神経腹側枝との間に 1 条の吻合が見られる。 左側鎖骨下綰尾側端，前後枝が再び合する高さで前枝 より出た 1 枝は, 神経幹と大動脈との間を下り, $\mathrm{D}_{2}$ 頭 側の高さで再び神経翰に入る。又 $\mathrm{D}_{2}$ 中央及 $\mathrm{D}_{3}$ 頭側 端の高さで夫久1枝を出し，これらは神経幹内側近く を下りつ」合して1条となり， $\mathrm{D}_{4}$ の高さで再び神経幹 に入る。

脊䪔神経との交通枝柱, 左側で第 5 到神経腹側枝 と上頸神経節尾側端との間に 1 条及 $\mathrm{C}_{8}$ より $\mathrm{L}_{2}$ まで の脊㕼神経腹側枝と交感神経幹との間火 1 万至 4 条の

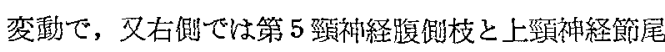
側端との間飞 2 条，第 6 頚神経腹側枝々鎖骨下綰頭側 端との間飞 1 条及び $C_{8}$ より $\mathrm{L}_{2}$ までの脊鲢神経腹㑡枝 と交感神経幹との間に 1 乃至 4 条の変動で見られる。 


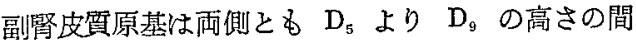
で, 大動脈の両側, 交感神経幹の腹側で，その柾断面

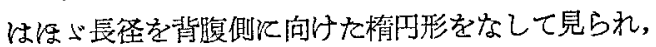
境界は比較的明瞪であるが，13 mm(a) 同様内側は不 明瞭である。副篮内側と腹大動脈との間に前盗椎神経 㵵原基をなす神経細胞群が散在して見られる。副腎檌道 筫紐胞は主として皮質内側周辺焟在し，一部腹側よ り外側周辺部にる認められ, 皮賀内一の侵入はまだ著 明でない。皮害内僛周辺部の髄質細胞群飞,左側は $\mathrm{D}_{5}$ 頭側の高さで交感神経幹より出た 1 枝が，有側では $D_{4}$ 尾側及 $\mathrm{D}_{5}$ 頭側の高さで交感神経幹より夫々出た 1 枝 が入る。これらは内䁍神経原基と思われる。副腎皮質 原基は $\mathrm{D}_{5}$ より $\mathrm{D}_{8}$ の高さの間で交感神経幹腹側と 接する。䯣質練胞詳と前脊椎神経叢とを形成する細胞 群及び交感神経幹との間は, 相互飞移行し, 明膫な竝 界線を引き難いところがある。右側では $\mathrm{D}_{9}$ の高さで

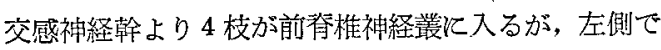
は認められない。両側とも $\mathrm{D}_{6}$ の高さで皮質原基内腹 側飞接して神経線維束が現かれ，尾側飞向万飞従つて

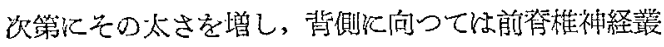
と吻合するが，交感神経幹との吻合は見られない。こ

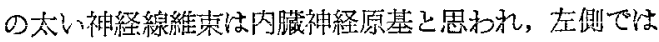
$\mathrm{D}_{9}$, 右側で壮 $\mathrm{D}_{8}$ の高さで終り, この経過中左側では $\mathrm{D}_{7}$, 右側では $\mathrm{D}_{6}$ の高さで, 両側の神経線維束の閻飞 大動脈の腹側を通り弧状を描く2条の吻合が見られ る。

腹腔神経装原基は $\mathrm{D}_{10}$ より $\mathrm{L}_{1}$ の高さの間で,大動 脈の両側から腹側化かけ, 多数の散在する神経細胞 群として認められるが，神経節状をなす細胞集団は未 だ見られない。この神経細胞群行交通枝を介して左側 で第 11 胸神経腹儧枝より 1 条, 第 1 腰神経腹傊枝 より 2 条，第 2 腰神経腹側枝より 1 条，右側では第12 胸神経腹側枝より 1 条, 第 1 及 2 腰神経腹側枝より夫 々 1 条の神経線維束が入る。又交感神経幹とは左側で は $\mathrm{D}_{11}$ 及 $\mathrm{D}_{12}$ の高さで夫々 1 条，右側では $\mathrm{D}_{10}$ の高 さで1条， $\mathrm{D}_{11}$ 及 $\mathrm{D}_{12}$ の高さで夫々 2 条， $\mathrm{L}_{1}$ の高さ で 1 条の吻合が見られる。向左右の交感神経幹の間 飞, 左側は $\mathrm{L}_{2}$, 右側恬 $\mathrm{L}_{1}$ の高さで大動脈の腹側を通 り崛状学描く 1 条の吻合が見られる。

5） $13 \mathrm{~mm}$ (a) 人胎児（附図参照，図 4)

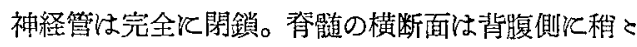
長い梢円形をなし，管腔法背腹の方向汇細長く，左右 の翼状板は管腔の中央部で相接し，管腔は腹側寄りと 背側寄りとに二分されている。左右両側壁は 3 層即ち
エペンディユウム・マント及周辺層に分化し，前索・ 後索及側索分認められる。脊䯑道神経節以左側 31 佪, 右側 32 個まで見られ，これらの全てK夫々それらか

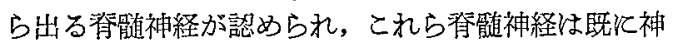
経䋥胞を伴つていない。頭神経附属の神経節も三㣔神 経から副神経まで皆存在する。

脳随左右の大脳半球膨出し, その膨出と間脳との つよ゙きにくびれが見られる。原始學腔は既に咽頭们 つて開口し，終脳壁より原始鼻腔内側们つて神経細 胞群が認められる。間脳から左右化突出する眼杯原

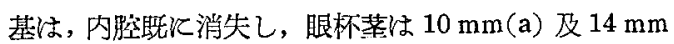
(K) そ比し更に細くなつている。色素圆顆粒は著しく 增している。視床原基をなす間脳壁の肥厚は $14 \mathrm{~mm}$ (K) 上りも愿くなつている。間脳中央部の漏斗を囲え で Rathke 氏葄が見られる。

滑車神経は $14 \mathrm{~mm}(\mathrm{~K})$ 例所見と同様。

動眼神経は間脳の外側, 半月状神経節内側に接する 前主静脈の内㑡近く通り, 眼球後下方部の細胞密集部 ・滑車神経終末部より少しく頭側で分枝して終り，そ の分肢する前後江て本幹の外側江接して毛椂神経節原 基と思われる細胞集団が見られる。此の神経䋖胞集団 と動眼神経さの閏には僅かながら神経線維による吻合 が見られる。

外旋神経估 $14 \mathrm{~mm}(\mathrm{~K})$ 例所見飞同椂。

三文神経。半月状神経節心周囲との境界明瞭とな りその内側神経線維束よりなる Portio minor が 見られる。

眼神経は頭側向いつ小二枝に分れ，一枝は眼球後 方を経てその上部終り，てれ杜前頭神経原基と考克 られる。他の一枝は眼球後方の細胞密集部にて分枝し て終り，乙の枝上り動期神経外側部代接する神経細胞 集団晌向つて一条の細胞条が見られ，これは毛様神経 節原基と考光られる。この細咆条と眼神経との䦩にす 僅かながら神経線維による吻合が見られる。

上顎神経は多数の分束として半月状神経節より出 て，主として上颚突起の部分で分散して終り，一部は 咽頭上外側部て翼口蓋神経節と考光られる疎らに散在 する細胞群中に終る。

下哿神経は舌・頓・耳側頭及下歯槽神経等に分れ， 舌神経は $\mathrm{C}_{2}$ の高さで顔面神経より出九鼓索神経と吻 合し， $\mathrm{C}_{3}$ 頭側端の高さで舌根外側部にて，舌神経内 背側に接して節状をなす神経細胞集団が見られる。乙 れは類下神経節原基と思われる。それより末梢に向つ

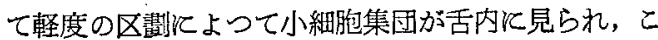


れは舌下神経節原基と思われる。又下顎神経が半月状 神経節から出る高さより少しく尾側の高さから下方に かけて, 下顎神経の内背側近くに散在する神経細胞群 が見られる。これは耳神経節原基と考学られる。この 細胞群汇下顎神経より出た 1 枝が入る。

顔面神経。滕神経節は $14 \mathrm{~mm}(\mathrm{~K})$ 飞比乙神経細胞 が密集し, 左側は $C_{1}$ 頭側端より少しく頭側，右側で は $C_{1}$ 頭側の高さで滕神経節より出る大浅岩神経は，

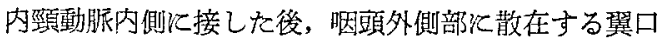
箩神経節原基と思加れる神経細胞群中终終る。鼓索神 経は両側とも $\mathrm{C}_{2}$ 頭側の高さで顔面神経上り出て, $\mathrm{C}_{2}$ キ央の高さで舌神経と吻合する。本幹は口塍外側の中 肧染中分散して終る。

聴平衡神経に附属する神経節及これから耳胞壁待達 する神経本が見られる。

舌咽神経は頭蓋内及外神経節は完全分吩し，外神 経節腹側より $\mathrm{C}_{1}$ 中央の高さで出た 1 枝は, 直ぐと 2 枝江分れ，1枝は直ちと咽頭背側近くて終り，他の 1 枝は内頸動脈より出る舌骨動脈汇接し，そこで終る。 これ鼓室神経原基と考へられ，顔面神経との吻合及 び耳神経節との連絡は未だ認められない。

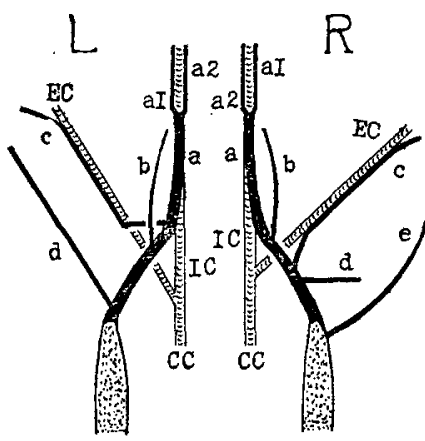

$14 \mathrm{~mm}(\mathrm{~K})$ 上缅神経節頭側

IC : 内 䁰 動 眽

$\mathrm{EC}$ : 外頸 動 㟲

$\mathrm{CC}$ ：総 頸 動 服

図 1

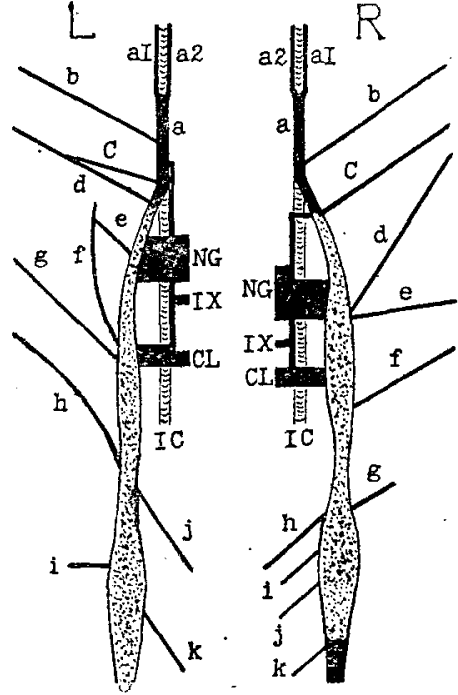

$13 \mathrm{~mm}$ (a) 上莖真 神 経 節 NG：節 状 神 経 節 IX : 舌 咽 神 経 CL：上喉頭神経 図 2
迷走神経では頸神経節及節状神経節は完全に分離 し，上㬋頭神経及反回神経も発育している。 $\mathrm{C}_{2}$ 及 $\mathrm{C}_{3}$ の高さて節状神経節，上喉頭神経及舌㸶神経俚交感神

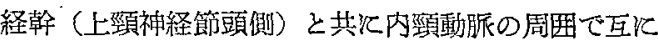
吻合して，神経鋠原基を形成している。本幹は食道己 気管との間の外側近くを下降しつ」，それらに枝を出 し，更に肺原基枝を出した後，胃の部分で終る。

副神経の神経節は耐側共相当大きく，神経管の外側

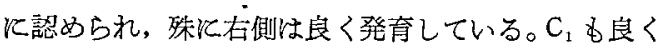
発育して居り，これと比較すると副神経の神経節の方 がや小小さい。 $C_{2}$ の高さで第 1 项神経腹側枝・舌下神 経及上頸神経節よりの枝が互汤合し，その吻合の磌

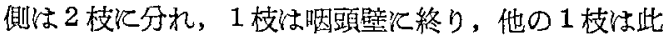
の副神経の神経節と吻合する。副神経の标随部は $\mathrm{C}_{7}$ の高さまで追求出来る。

舌下神経は左右とも3 個の神経束となつて腹尾側方 へ向いつ」, 次第儿1 条の神経束となり, 節状神経節 背側近くで上葝神経節よりの 1 枝及第 1 到神経腹側枝 乙吻合する。本幹山舌内分散して終る。下行枝は $\mathrm{C}_{4}$ の高さで, 内頸静服背外僛部で第 1,2 及 3 頸神経 腹側枝と吻合して舌下神経綰を作る。 
$-70-(1164)$

交感神経幹原基は上位涇部より似部注たなて見ら れ，周囲との境界明瞭て概ね節状をなしているが，こ れら各節間学連絡して縦走する神経線維束は, 殊に頸 部及上位胸部では神経細胞を伴つているとこるが多 い。交感神経幹は両側とも $C_{4}$ 及 $C_{5}$ の高さで膨大して 上项神経節原基を形成し，多数の神経細胞の密集が見 られる。 $\mathrm{C}_{3}$ の高さで節状神経節内側に接している。

上頸神経節頭側は両側とも $\mathrm{C}_{2}$ 及 $\mathrm{C}_{3}$ の高さで節状 神経節, 上喉頭神経及舌咽神経等已共に, 内頸動脈の 周囲で吻合している。(以下艘図 2 参照)。

左側上頸神経節頭側からは $\mathrm{C}_{2}$ 及 $\mathrm{C}_{3}$ の高さで a.b •c・d・e.f 及 $\mathrm{g} の 7$ 枝が出て, a 枝は最も太く, 内頸 動脈神経原基となつて内頸動服背側江接して上り, 内 莖動服より舌骨動脈が出る所て $\mathrm{a}_{1}$ 及 $\mathrm{a}_{2}$ の2枝に分 れ， $a_{2}$ 枝は直ちに内頸動脈内側に接して終り, 外側 に接して上る $a_{1}$ 枝は $C_{1}$ 頭側端の高さで大浅岩神経 と吻合して終る。b 枝忹節状神経節頭䁚端と吻合す る。 $\mathrm{c}$ 枝は $\mathrm{d}$ 枝と合して 1 条となり, 其後再び $\mathrm{d}_{1}$ 及 $\mathrm{d}_{2}$ の2枝に分れ， $\mathrm{d}_{1}$ 枝は更に2 枝に分れ，1枝は節 状神経節頭側端と吻合し”，他の 1 枝は舌㸶神経の頭蓋 外神経節頭側端々吻合する。 $\mathrm{d}_{2}$ 枝更に 2 枝に分れ， 1 枝は節状神経節頭㑡端と吻合し，他の 1 枝は頭蓄外 神経節泣側の内側倿近しつ今終り,これとの吻合は 明らかでない。e枝と $\mathrm{f}$ 枝も合して1本となり，輕静 脈内側飞終る。左側上頸神経節㤌更に $\mathrm{C}_{4}$ の高さで $\mathrm{h}$. i 及 $\mathrm{j}$ の 3 枝， $\mathrm{C}_{5}$ の高さて $\mathrm{k}$ 枝学出す。 $\mathrm{g}$ 及 $\mathrm{h}$ 枝は副神経 - 舌下神経及第 1 项神経腹側枝等乙吻合乙 て神経丵孝形成し，これより 3 枝を㖿頭壁飞出す。i ·枝は明頭壁化入す。 $\mathrm{j}$ 枝節状神経節尾側よりの 1 枝 乙吻合した後 $j_{2}$ 及 $j_{2}$ ○2 枝に分れ， $j_{1}$ 枝は $\mathbf{k}$ 枝上 吻合して更に 2 枝に分れ，1枝は $\mathrm{C}_{6}$ 頭側の高さで左 側総频動脈背側近くで終り，他の 1 枝は迷走神経背側 そ接するが，これと吻合することなく再び維れ， $\mathrm{C}_{7}$ の高さで下行大動脈外背側で小細胞群てつぶいて終 る。 $\mathrm{j}_{2}$ 枝は迷走神経と吻合した後 2 枝化分れ，1枝小 $\mathrm{C}_{6}$ の高さで左総到毁脤加ら Truncus brachioceph. を経て大動脈弓ほ達するまでの間の動脈北側及外側て 小細胞群につよ゙いて終り, 他の 1 枝は迷走神経と吻合 した後， $C_{6}$ 尾側端の高さで更に 3 枝何分れ，1枝は 大動脈局腹側てて小細胞群てつがいて終り，他の 2 枝 は在側迷走神経よりの枝と吻合し， $\mathrm{C}_{7}$ の高さで大動脈 弓装側飞て小細胞群沉ついて終る。

右側上頸神経節頭側は $\mathrm{C}_{2}$ 及 $\mathrm{C}_{3}$ の高さで $\mathrm{a} \cdot \mathrm{b} \cdot \mathrm{c} \cdot \mathrm{d}$ 及eの 5 枝儿分れる。a 枝は左側 $\mathrm{a}$ 枝と同様内頸動脤
神経原基となり，舌骨動脈が出る高さより少しく頭側

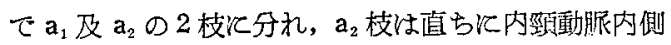
で終り， $a_{1}$ 枝は外側に接して上り， $C_{1}$ の高さて大浅 岩神経と吻合して終る。c枝は 2 枝儿分れ，1枝はb 枝と合して頭蓋外神経節に終り，他の1枝は節状神経 節より少しく頭側で迷走神経と吻合する。d枝字 2 枝 に分れ，1枝は舌下神経と吻合し，他の 1 枝は頸静脈 内側泈る。 $\mathrm{e}$ 枝及 $\mathrm{C}_{3}$ の高さで上新神経節より出る f枝は, 副神経の枝, 舌下神経の枝及第 1 及 2 莖神経 腹側枝等と吻合して神経策を形成し，これより 3 枝を 咽頭壁治す。右側上项神経節は更に $\mathrm{C}_{4}$ の高さで $\mathrm{g}$. $\mathrm{h}$ 及 $\mathrm{i}$ の3枝， $\mathrm{C}_{5}$ の高さで $\mathrm{j}$ 及 $\mathrm{k}$ の2枝を出す̀。 $\mathrm{g}$ 枝は咽頭壁江終る。h 枝は迷走神経と吻合した後, $\mathrm{C}_{5}$ 䫒側の高さで右側総项動脈背側にて小細胞群につが いて終る。i 枝は $C_{5}$ の高さ，右総頸動脈加巨鎖骨下 動脈沈けてつぶき，鎖骨下動脈背側にて，j 枝はそ の外側， $\mathrm{k}$ 枝はそれより少しく尾側の高さでその背側 にて、いつれる小細胞群につがいて終る。

上頸神経節は両側とも $\mathrm{C}_{3}$ の高さては節状神経節内 側飞接し, それより尾側に向つては, 節状神経節倿 しつょ内側より内背側飞移り, 左側では $\mathrm{C}_{4}$ 頭側端, 右側では $\mathrm{C}_{3}$ 尾側端の高さで節状神経節より離れ，食 道原基の両側を経て， $\mathrm{C}$ ，の高さで脊椎原基の腹外側 面江近つく。右側では $\mathrm{C}_{5}$ 及 $\mathrm{C}_{6}$ 頭側の高さで細くく びれて神経線維束となり， $\mathrm{C}_{6}$ 中央の高さで細い前枝 2 本と太い後枝 1 本の 3 枝分れ，その夫々の間を背側 方へ乙春椎動脈，外側方一鎖骨下動脈が走つて鎖骨下 綰原基を形成する。 3 枝は $\mathrm{C}_{7}$ 頭側の高さで再び合し て，1本となり，膨大して神経細胞も密集し，下頸神 経節原基となる。左側では $\mathrm{C}_{6}$ の堂さで細くくびれて 神経線維束となるが，鎖骨下綰を全く欠き，その傾向 さ光も見られず，鎖骨下動脈はその腹側を横切る。C の高さで再び膨大して下䫓神経節原基を形成する。

交通枝は両側とも $\mathrm{C}_{8}$ より $\mathrm{L}_{1}$ までの宜䯣神経腹唰 枝と交感神経幹との間江 1 万至 3 条の変動で見られ る。文交感神経幹より A. segmentalis dorsalis K $\mathrm{C}_{5}$ より $\mathrm{L}_{2}$ の高さの閻で左右対称的行細い枝を出して いる。内茂神経原基は左側は $\mathrm{D}_{4}$, 右側は $\mathrm{D}_{5}$ の高さ て交感神経翰腹側より分れて始まる。

副腎皮質原基恼雨側とも $\mathrm{D}_{\mathrm{6}}$ より $\mathrm{D}_{\mathrm{i} 0}$ の高さの間 で，腹大動脈の雨側，交感神経幹の腹側こ，その横断 面言玨を稍と内腹側から外背㑡へ向けた棈门形をな して見られ，境界は比較的明䐲であるが，内側は不明

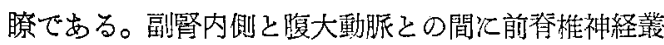




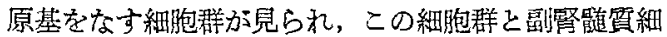

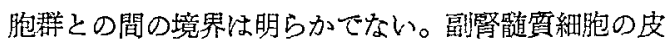
質内一の侵入は未だ著明でなく，主として皮質内側周 辺部行散在して認められる。内贜神経より前脊栍神経

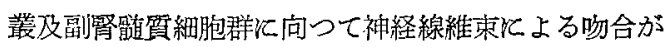
兒られるが，交感神経幹との吻合住認如られない。雨 側前脊椎神経丵間化 $D_{7}$ の高さで, 副堅皮質内腹側で 大動㟲腹側を通り弧を描く 1 条の著明な太い吻合が見 られ，この神経線維束と留壁背僛の迷走神経丵原基と の間化1条の細い吻合が認められる。又此の弧状堂描 く昒合は夫久両側て内臟神経と吻合している。

腹腔神経對原基は $\mathrm{D}_{3}$ より $\mathrm{D}_{12}$ の高さの間で,大動 脈の両側から腹㑡てかけて, 多数の散在する神経細胞 群として認められる。向大動脈腹唧で, 此の神経丵頭 側及尾溉江各 1 対の大神経細胞集団が節状をなして認 められ，尾側の方分頭側のるのよ大きい。これらは 腹腔神経節原基と思われる。尾側の 1 対沉, 左㑡では $\mathrm{D}_{10}$ 及 $\mathrm{D}_{11}$ の高さで夫々 1 条, 右側では $\mathrm{D}_{11}$ の高さ で1条の神経線維束が交感神経翰より入る。左右交感 神経幹の間に $\mathrm{D}_{12}$ の高さで, 大動㟲の腹側を通り弧状 を描く 1 条の太い神経線維宋の吻合が見られる。

6） $20 \mathrm{~mm}$ 人胎児(附図参照，図 5 )

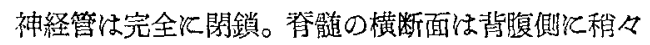
長い棈円形をなし，管腔は去の背側部で左右の翼状板 が相接し，殆んぞ消失して線状となり，腹側沉中心管 を形成している。管腔の両側な 3 㬝即ちエペンディユ ウム・マント及周边層江分化に, 前索・後索及側索が 䜅められる。脊髄神経節は 33 対で, これらの全てに

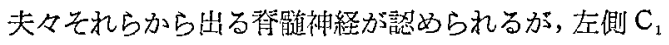

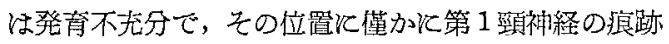
を認める汇過ぎない。頭神経附属の神経節は三文神経 から副神経まで皆存在する。

脳㶡道。左右の大脳半球の膨出は $13 \mathrm{~mm}(\mathrm{a})$ 上り更に 発達し，その膨出と閻脳とのつがきのくびれが著明と

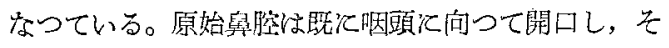
の内側流 $13 \mathrm{~mm}$ (a) 上り更に多数の神経網胞群が見 られる。視床原基をなす間䏚壁の肥厚山 $13 \mathrm{~mm}(\mathrm{a})$ と 同様。視床下部より左右汇突出する眼菜は, 内部の中 腔消失乙神経線維の增加加見られる。眼杯及水晶体小

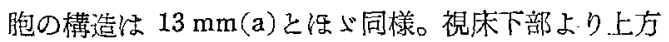

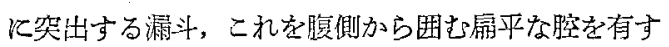
る Rathke 氏䨘等の形も $13 \mathrm{~mm}(\mathrm{a})$ と同㥞て，この

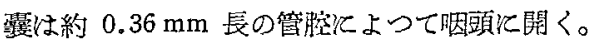

滑車神経江 $13 \mathrm{~mm}(\mathrm{a})$ と同様で,神経交攴も明瞭炕
見られ，中脳外例を腹側次向い，動眼神経の外側を経

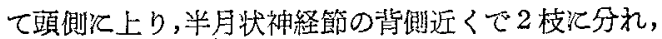
1枝は半月状神経節より出た眼神経飞吻合し, 他の 1 枝も眼神経と吻合した後, 眼球後下方の細胞密集部门 終る。

動眼神経も治ざ $13 \mathrm{~mm}$ (a) と同様で,眼球後方でそ の外側て接して毛样神経節原基と思われる紐胞集团が 見られ，動眼神経と此の細胞集団との間注神経線維 そよる吻合が恐められる。

外旋神経注動眼神経の下方を走り，眼球後方下部の 細胞密集部て分枝して終る。右側では毛様神経節と2 条の吻合が見られ，左側では毛様神経節より外旋神経 飞向つて1条の神経線維束が見られるが，中途で消失 し吻合は明らかてない。

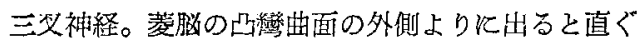
飞半月状神経節を形成し, その内僛神経線維束上り なる Portio minor が見られる。眼神経は半月状神経 節を出て頭側江向いつ」 2 枝分分， 1 枝は眼杯後方 を経て眼球上方の中还葉中《終りこれは前頭神経原 基と考えられる。他の 1 枝は眼球下部们向つて 1 枝を 出乙た後，この枝より眼球後方で動眼神経外側部に接 する神経細胞集団汇向つて1条の細胞条が見られる。 これは毛様神経節原基と思われる。この細胞条と眼神

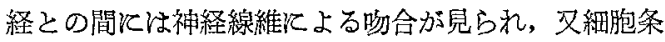
中《も神経線維が認められる。次いでこの眼神経の枝 认頭側汇上り，原始鼻整外側の中胚葉中で終り，これ 以鼻毛样神経原基と思蛙れる。

上颚神経柱半月状神経節より出ると間もなく多数の 分束となり，その内側汇散在する翼口蓋神経節原基を なす紐胞群征一部の神経束は大り，他の大部分は外側 夓突起内分散して終台。

下顎神経柱注ら゙ $13 \mathrm{~mm}$ (a) と同様所見で,その末梢

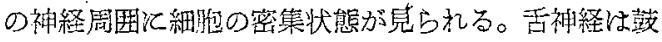
索神経と吻合し，てれより少しく星側 $C_{1}$ の高さ，舌 根部外側で，その内背側沉接して故下神経節原基をな 寸神経細胞集団が見られ，それより末梢炕向つて軽度 の区劃汇よつて小細胞集団がありこれは舌下神経節 原基と思かれる。左浿で记下觉神経が半月状神経節か ら出る高さ，右側ではそれより少しく尾側の高さから 下方的加て，下顎神経の内背側近くに神経細胞集团 が認められ，これは耳神経節原基と思われる。この細

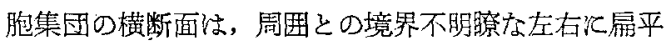
な不正棈円形をなし，全体の形は头端を頭側向けた

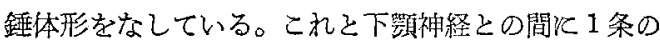


苟合が見られる。

顔面神経。膝神経節原基は $13 \mathrm{~mm}$ (a) 飞比し細胞 の密集状態は倯々粗である。左側は $\mathrm{C}_{1}$ 頭側端より約 $460 \mu$ 磌㒋, 右側怕 $840 \mu$ 頭側の高さで膝神経節尾 側より出た大浅岩神経は，内頸動脈内側に接し，と小 で内頸動脈神経と吻合した後, 咽頭外側部に散在する 翼口䇪神経節原基をなす細胞群中终る。左側は $\mathrm{C}_{2}$ 頭側端より，在側快 $\mathrm{C}_{i}$ 頭側端より何れも約 $100 \mu$ 頭 側の高さで顔面神経より出る鼓菜神経は, 頭側化上り 舌神経之吻台する。本幹法口堙外腹側の中肧葉中汇分 散して終る。

聴平萬神経。前庭神経節及蝸牛嗀神経節及びこれら から耳胞壁洼する神経束が見られる。

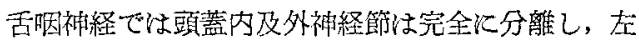
側は $\mathrm{C}_{1}$, 右側は $\mathrm{C}_{1}$ 頭側端より約 $200 \mu$ 頭側の高さ で外神経節頭僛端より出た鼓室神経は，直らに2枝に

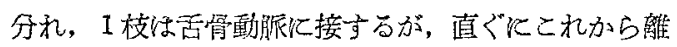
れ，再び他の1枝と合して1本となり，胭頭背側近く を外側方顔面神経任向う。左側ては膝神経節より大浅 岩神経が出る高さで膝神経節腹側と吻合し，小浅岩神 経となつて耳神経節原基飞, その外背側より入つて終

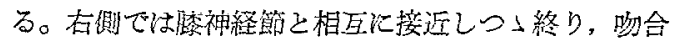
は明らかでないが，小浅岩神経と推定される。

迷走神経电 $13 \mathrm{~mm}$ (a) そ殆んそ同㥞て， $C_{2}$ の高さ で節状神経，これがら分枝する上堠頭神経及舌胭神経 が交感神経幹 (上项神経節頭側)の外側飞接して居り, 交感神経幹は内頸動眽の背側及腹側で節状袖経節乙， 腹側で上喉頭神経及舌咽神経と吻合する。迷走神経の 本幹は食道と気管の简の外側近くを下降しつょ, それ

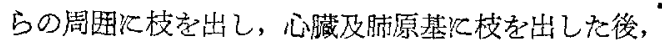

青の部分で終る。

副神経の会䯣部は左僛は $\mathrm{C}_{3}$, 右側は $\mathrm{C}_{2}$ の高さま で追求出来る。

舌下神経は左右とも3 個の神経束となつて腹尾側方 へ向い, 最頭側の神経束な極めて細い。後頭骨の舌下 神経管原基内て互に相接し，管を出て迷走神経背側に 向いつ〉次第に 1 条の神経束となり，節状神経節背側 に接し，次いで艺背側より外側を経て腹側洺り，

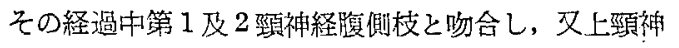
経節よりの枝之女物分が見られる。本幹恬中に分散 して終る。下行枝は $C_{4}$ の高さで,内頸静跟背外側部で 第 2 及 3 頸神経腹側枝と吻合して吉下神経綰を作る。

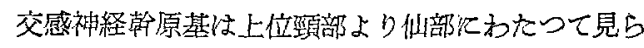
れ、周国とは明瞭傹され，殆んどその全長にれたつ
て節状をなし，去れらを連絡する縱走る神経線維束 は殆んぞ細胞を伴つていない。交感神経幹は两側とも $\mathrm{C}_{3}$ より $\mathrm{C}_{5}$ の高さの間で著しく膨大し，上頊神経節 原基となり,多数の神経細胞の密集が見られる。 $\mathrm{C}_{2}$ 及 $\mathrm{C}_{3}$ 頭側の高さで節状神経節内側火接し,それょり尾側 飞向つては次第に節状神経節の内背側上り背側へと， これに接しつ」移り, 左側は $\mathrm{C}_{3}$ 尾側, 右側は $\mathrm{C}_{4}$ 尾 側の高さで背側万へ移動して行くため迷走神経よりは 離れて行き，食道原基の雨側定さら反背側万反移動し て腰椎上部ては春椎原基の腹外側面炕達する。

上頸神経節頭側恓乘側己も $\mathrm{C}_{3}$ の高さで節状神経節，

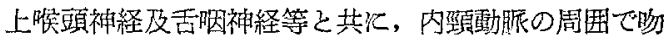
合している。(以下插図 3 参照)。

左側上頸袖経節頭側は $\mathrm{C}_{2}$ の高さで a,b,c 及 d 4 枝に分れ，a枝は最多太く，内頸動脈神経原基とな つて内頸動脤背側飞接して上り，内頸動脤より舌骨動 脈が出る高さて $a_{1}$ 及 $a_{2}$ の2枝分れる。内頚陲脈 外側飞接して上る $a_{1}$ 枝は大浅岩神経と物合して終る。 内项動脈の内側倿して上る $\mathrm{a}_{2}$ 枝は $\mathrm{a}_{1}$ 枝が終る高

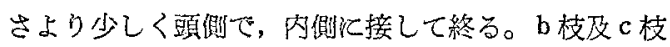
は互に相接して節状神経節内側，a枝背側近くを顽側 飞上り，b枝はa枝と吻合して秋り，c枝はb枝が終 る䯩さより少しく尾㑡で，b枝より媰隹れて背側飞向 う。 $\mathrm{C}_{3}$ 尾側端の高さで上頸神経節より出た $\mathrm{e}$ 枝は，上

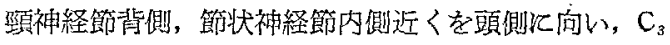
の高さで $\mathrm{e}_{1} \cdot \mathrm{e}_{2}$ 及 $\mathrm{e}_{3}$ の3枝, $\mathrm{C}_{2}$ の高さで $\mathrm{e}_{4}$ 及 $\mathrm{e}_{5}$ の 2 枝を出した後， $\mathrm{d}$ 枝と吻合して 1 条となつて上

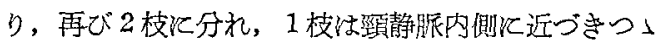
終り，他の 1 枝恬上記 $\mathrm{b}$ 枝より離れて背儧飞向 $5 \mathrm{c}$ 枝 そ吻合し， $\mathrm{C}_{1}$ の高さで頸静脈内側近くで神経節状をな

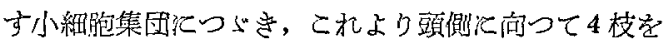
出す。この4枝の中，第1枝は Occipitalbogen の表 面で終り，第 2 枝は頭蓋外神経節頭側端内側儿近づき つ〉吻合することなく終り，第 3 枝は節状神経節と頸 静脈神経節との中間の高さで迷走神経と吻合して終 り，第 4 枝は頭蓋外神経節頭側端内側に接してこれと 吻合した後, 外転して Basalplatte と Pars cochlearis との間の Perichondral K終る。上記e枝上り分礼た $\mathrm{e}_{1} \cdot \mathrm{e}_{2} \cdot \mathrm{e}_{3} \cdot \mathrm{e}_{4}$ 及 $\mathrm{e}_{5}$ の 5 枝は第 1 及 2 项神経腹側枝及 び舌下神経と吻合して神経蕞を形成し，てれょり6枝 を咽頭壁汇出す。） C 4 简さで上頸神経節より $\mathrm{f}$ 枝を 咽頭壁江出し，この枝は上記神経叢の枝々咽頭壁内に て吻合する。又上铰神経節より $\mathrm{C}_{3}$ の高さで出た h 枝, $\mathrm{C}_{4}$ の高さで出た $\mathrm{i}, \mathrm{j}, \mathrm{k}$ 及 1 枝は上㬋頭神経及 
迷走神経（節状神経節尾側端）よりの枝と吻合して 1 条となり，C，の高さで再び 4 枝に分れる。第 1 枝は $\mathrm{C}_{4}$ 尾側端の高さで上頸神経節より出た $\mathrm{o}$ 枝と吻合し て1条となり， $\mathrm{C}_{5}$ 尾側端の高さで交感神経幹腹側代 近づきつ〉，吻合することなく終る。第 2 及 3 枝は $\mathrm{C}_{7}$ の高さで左右迷走神経からの枝と共沉，大動脈号

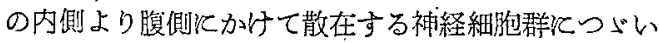
て終る。第 4 枝は $\mathrm{C}_{6}$ の高さで迷走神経と吻合した後 3 枝分れ，2枝は左総頸動脈から大動脈开へかけて 動脈背側で，他の1枝はその外背側で，何机も散在す る小神経細胞群伛つがいて終る。C $C_{4}$ の高さで上项神 経節上り出る $\mathrm{m}$ 及 $\mathrm{n}$ 枝は， $\mathrm{C}_{6}$ 高さで勿合して1条と なり，迷走神経の内背側化接しつお，これと吻合する ことなく終る。

右側上项神経節頭側は $\mathrm{C}_{2}$ と $\mathrm{C}_{3}$ の間の高さて細く くびれて神経線維束となり, 頭側方 $\mathrm{C}_{2}$ の高さでさ い神経節を形成し，これより d,e 及 $\mathrm{f} の 3$ 枝を出し，

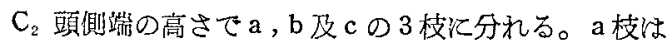
左側乙同樣最を太く，内栭動踏神経原基となり内頸動 眽背側て接して上り, 舌骨動脈が出る高さより少しく 尾側の高さで $a_{1}$ 及 $a_{2}$ の 2 枝に分れ，外側接して 上る $a_{1}$ 枝は大浅岩神経と吻合して終り，内側炕接して 上る $a_{2}$ 枝は $a_{1}$ 枝が終る高さより少しく頭側沉て内頸 動脈淁して終当。b 枝とd枝は合して1条となつて $\mathrm{a}$ 枝背側近くきり， $\mathrm{C}_{1}$ の高さで再び 2 枝に分れ， 1 枝は a 枝と吻合し，他の 1 枝は頸静脈神経節尾側端已 伆合する。e枝と $\mathrm{f}$ 枝す合して1条となつて節状神経 節内側话くを上り， $\mathrm{C}_{1}$ の高さで再び 2 枝に分れ， 1 枝 は節状神経節頭側端背側任近づきつ小終るが，吻合柱 明らかでなく，他の1枝は $\mathrm{c}$ 枝て合し，迷走神経内側 近くで神経節状をなす小細胞集団となり，これより頭 側化向つて 2 枝を出す。1枝は頭蓋内神経節上り少し く尾儧の高さで舌胭神経と吻合し，他の 1 枝は到静脤 神経節々節状神経節の中間の高さで迷走神経と吻合乙 て終る。上頸神経節より $\mathrm{C}_{3}$ の高さで $\mathrm{g}$ 及 $\mathrm{h} の 2$ 枝， $\mathrm{C}_{4}$ の高さで $\mathrm{i}$ 及 $\mathrm{j}$ の 2 枝を出し， $\mathrm{g}$ 枝惊更飞 $\mathrm{g}_{1} ， \mathrm{~g}_{2}$ 及 $g_{3}$ の 3 枝儿分れ，乙れらは第 1 及 2 頸神経腹側枝 及び舅下神経と吻合して神経丵を形成し，これより 5 枝を咽頭壁汇出す。又 $\mathrm{C}_{4}$ の高さで上頸神経節より $\mathrm{k}$, $1, \mathrm{~m}$ 及 $\mathrm{n} の 4$ 枝， $\mathrm{C}_{s}$ の高さで。枝を出す。 $\mathrm{k}$ 枝は 右㑡上喉頭神経と吻合した後， $\mathrm{C}_{5}$ の高さで右総頸動 脈内背側徣在する神経細胞群沉つら゙いて終る。1 及 n 枝は右側迷走神経上りの枝々吻合した後, $\mathrm{C}_{5}$ 及 $\mathrm{C}_{6}$

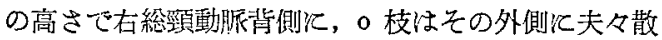

在する神経細胞群㐳つがいて終る。 $\mathrm{m}$ 枝は上頸神経節 内腹側淁して下り, 尾側向 5 に従つて内背側飞移 り，。枝の出る高さで再び上頸神経節沉入る。

両側とも上頸神経節尾側は $\mathrm{C}_{6}$ の高さで細い神経線 維束となり，C７高さで前後の 2 枝伢れ，後枝は太 く前枝は紐く，鎖骨下綰原基を形成し，その間飞鎖骨 下動脈を创み，再び前後枝の合する $\mathrm{C}_{7}$ 尾側の高さよ り $\mathrm{C}_{8}$ の高さに加忷て再び膨大し，下媔神経節原基と なり，多数の神経細胞の密集が見られる。

交通枝少両側とも $\mathrm{C}_{6}$ より $\mathbf{L}_{4}$ までの脊娟道神経腹㑡 枝と交感神経幹との間化 1 万至 4 条の変動で見られ る。又交感神経幹より A. segmentalis dorsalis $\nwarrow$ $\mathrm{C}_{8}$ より $\mathrm{L}_{1}$ の高さの間で左右対称的汇細い枝を出す。 右側交感神経幹内側より $\mathrm{D}_{1}$ 頭側の高さで出た 2 枝は 合して1条となり，食道背㒋近くを下り，交感神経幹 より $\mathrm{D}_{1}$ 尾側及 $\mathrm{D}_{2}$ 頭側の高さで出を各 1 枝と吻合し そ後, 大動哌々脊椎原基との間を走る奇静脈背側江接 して下り， $\mathrm{D}_{5}$ 頭側の高さで背側倿したま子終る。 左側交感神経幹内側上り $\mathrm{D}_{2}$ 尾側の高さで出た 1 枝法 奇静脈背側倿して下り， $\mathrm{D}_{3}$ 尾側の高さで再び神経 幹に大る。

內藏神経原基は左側は $\mathrm{D}_{4}$ 尾側, 右側怯 $\mathrm{D}_{5}$ 頭側の 高さで交感神経幹腹側より分れて始まり，神経幹腹側 飞接して下り，尾側に向うに従つてその太さ增す。 左假内臓神経より $\mathrm{D}_{6}$ 頭側端の高さで出た 1 枝は奇静 脈江接して頭側淌い， $\mathrm{D}_{4}$ の高さで静脈壁終る。 又左僛交感神経幹より $\mathrm{D}_{7}$ の高さで出た 1 枝も奇静脈 飞接して上り， $\mathrm{D}_{5}$ の高さで静脈壁に終る。右側交感 神経幹より $\mathrm{D}_{5}$ 尾側の高さで出た 1 枝は奇静脈背側保 接して下り， $\mathrm{D}_{7}$ 頭側端の高、さで 2 枝汇分れ， 1 枝は 再び神経幹沉入り, 他の 1 枝は $D_{7}$ 尾側の高さで内淢 神経化入る。右側内茂神経より $\mathrm{D}_{6}$ 星側の高さで出た 枝は奇静脈淁して上り， $\mathrm{D}_{4}$ の高さで奇静脤内側， 大動脈外背側近くで小細胞群につがいて終る。

副督皮䨘原基は左側で敋 $\mathrm{D}_{5}$ より $\mathrm{D}_{10}$ ，右側では $\mathrm{D}_{6}$ より $\mathrm{D}_{10}$ の高さの間で認められその横断面は長径を 頭側では内腹側より外背側と，尾側では腹背々向けた 椅円形をなし，周囲との境哭は明䐲である。頭儧で 交感神経幹とは胸腔沉よつてはるか腹側と距てられて いるが，尾溉向う火徉つて次第飞相接近し，左側て は $\mathrm{D}_{7}$, 右側では $\mathrm{D}_{8}$ の高さで内臟神経と接し,大動脤 の両側江位置する。この高さより尾側加けて内臓神

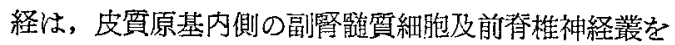
形成する細胞群晌向つて枝を出す。䯣質細胞主とし 
$-74-(1168)$

て皮質原基内側，一部は腹側周辺部認められ，これ 上り皮質内への侵入は著明てある。両側とる $\mathrm{D}_{6}$ の高 さで皮䝯原基内腹側淁して始まる神経線維束ね, 尾 側问 万に従つてその太さを増し, 且, 皮賈原基内背 側へと延び， $\mathrm{D}_{7}$ の高さで左右の間に大動脈腹側て 1 条の太い吻合をなし, 此の吻合は霄壁の迷走神経叢原 基と更に 1 条の吻合をする。上記神経線維束は䯣質細 胞群及前脊椎神経叢を形成する細泡群伎を出し, 左 側は $\mathrm{D}_{7}$, 右側は $\mathrm{D}_{8}$ の高さて内蔵神経と吻合し,左右 の間には更に $\mathrm{D}_{8}$ 及 $\mathrm{D}_{9}$ の高さで夫々 1 条の大動脈腹 側老通る吻合が見られる。

腹腔神経叢原基は $\mathrm{D}_{9} よ り \mathrm{D}_{12}$ の高さの間で,大動 脈の両側から腹側てかけて, 多数の神経細胞群として 認められ，又比較的周囲之の境界明睹な大紐胞集団も その中に見られる。これは腹腔神経節原基と思われ る。との腹䶼神経箃原基と交感神経幹より左側では $\mathrm{D}_{9}, \mathrm{D}_{10}$ 及 $\mathrm{D}_{11}$ の高さで各 1 条, 右側では $\mathrm{D}_{10}$ の高 さで 2 条, $D_{11}$ の高さて 1 条の枝を出す。左右交感神 経翰の間化 $\mathrm{D}_{12}$ の高さで 1 条， $\mathrm{L}_{1}$ の高さで 2 条の大 動脈の腹側を通り弧状を描く吻合が見られる。

\section{総括}

1) Streeter $\omega$ horizon XIV に鹤する発育段階 07 $\mathrm{mm}$ 人胎児では, 交感神経幹は大体脊䯣神経節江相当 した分節状に断続する神経細胞菜として，上頸部より

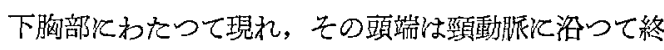
る。その細胞の配列次よつて上頸神経節及鎖骨下綰原 基と思われる構造が考光られる。頭部には未だこの神 経節原基と思われるるのは認めない。また前脊椎神経 叢 (prevertebral plexuses) 原基と思われるるのる認 められない。

2) Streeter $の$ horizon XV 亿属方発育段階の $6 \mathrm{~mm}(\mathrm{~K})$ 人胎児で，交感神経幹は上巠頁部より上腰 部に逆し，細胞集団は前段階に比してずつと連続的と なりその中多少の線維を認め始める。脊就神経前 枝加らの吻合枝は胸部ては殆んど線維性になつてい る。しかし交感神経幹の分節構造は未だ明らかで

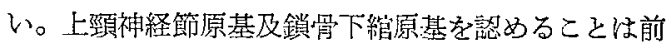
同様で，鎖骨下綰原基注未だ全く細狍性である。尾側 方には前脊椎神経倾原基となると思われる細胞群が， 大動脈の左右雨側涀われているが，左有は互に別々 で連続する様子はない。

3）Kuntz Kよると交感神経幹の見光始めは $5 \mathrm{~mm}$ で，下位胸部から上位腹部にわたり，6 $\mathrm{mm}$ ては下位 栭部から仙部犯たつているという。著者の例はこれ
そ較ベると，ずつと頭側てずれて発生し始めている。 即未だ交感神経幹が細片集団の断続によつて現わされ ている早期のもので, 既征上頸部から胸部林て 居り，次にそれよりる細胞集団の連続している胎児て， 上頚部から上腰部て及んて，仙部てまで及でいな wo

4) 脊髄神経前枝と交感神経幹とを連絡する交通枝 は, 最早期厄ては細胞条儿上り現わされ, 著者の $7 \mathrm{~mm}$ 例ては第1頸神経から右は第 10 胸神経まで，左は第 5 胸神経まで，各節例外なく存在する。次の $6 \mathrm{~mm}$ 例 では頸部に於てはこの吻合枝は知張り絀胞性てある が，第 8 頸神経以下第 1 腰神経まで殆えど線維性の 構造となり, 頭側方は次の $10 \mathrm{~mm}$ 例でも未だ細胞性 であるが，尾側方は腰部の下端て延びるるのは皆線維 性である。且この $10 \mathrm{~mm}$ 例では頸部の第 1 及第 7 の 交通枝が欠如している。10 mm 例以上ては频部て於的 る交通枝の欠如は，表に示した如く不規則で，この交 通枝の萎縮現象が決して規則的に行われるものてない ことを示している。その交通枝の残存しているるのは 皆線維性となつている。

5) 著者の $10 \mathrm{~mm}$ (a) 人胎児は Streeter $の$ horizon XVI の発育段卦江属するすので, その交感神経幹の発 育程度は Streeter の $10 \mathrm{~mm}$ 人胎児とほよ゙一致し， まだ連続せる細胞索として認められるだけで，この連 続せる細胞索に於ける細胞の配列によつて，いくらか 分節的構造は考えられるけれども, 線維の発育てよつ て分節構造を作り始める様子は見られない。Streeter の $10 \mathrm{~mm}$ 例では，上方の 3 分節榛髄神経前枝との結 合を欠如すると元うことであるが，著者の例では前述 の如く第 1 及第 7 飞於いて久如する。㞋 Streeter $の$ 例ては交感神経幹の頚側端が, 内頸動脈に㳂つた延長 として器められないとのことであるが，著者の例では $7 \mathrm{~mm}$ 例から既火ての像力現わ机ている。又 Streeter の例ては尾㑡方は下位仙椎まで交感神経幹が延びてい るとのことであるが，著者の例では第 2 腰椎位迄であ 当。

6) 以上の如くStreeter の horizon XVI までは, 交感神経幹原基は大体細胞索乙して脊随神経節及神経 管から由来すると思われる細胞の撒布により構成さ

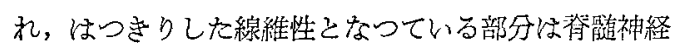
からの交通枝のみである。この大体全体㶩たつて細 胞性の状態の交風神経幹飞ついて, 上神経節, 鎖骨下

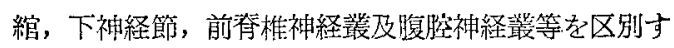
ることが出来る。副㹂原基は $7 \mathrm{~mm}, 6 \mathrm{~mm}(\mathrm{~K})$ 及 10 
艾感神経幹と垈碱神経腹側枝との間の交通枝

\begin{tabular}{|c|c|c|c|c|c|c|c|c|c|c|c|c|c|c|c|c|c|c|c|c|c|c|c|c|c|}
\hline & & $\mathrm{C}_{1}$ & $\mathrm{C}_{2}$ & $\mathrm{C}_{3}$ & $\mathrm{C}_{4}$ & $\mathrm{C}_{5}$ & $\mathrm{C}_{6}$ & $\mathrm{C}_{7}$ & $\mathrm{C}_{8}$ & $\left|D_{1}\right|$ & $\mathrm{D}_{2}$ & $\mathrm{D}_{3}$ & $D_{4}$ & $D_{5}$ & $D_{6}$ & $D_{7}$ & $\mathrm{D}_{8}$ & $D_{9}$ & $\mathrm{D}_{10}$ & $\left|D_{11}\right|$ & $D_{12}$ & $\mathrm{~L}_{1}$ & $\mathrm{~L}_{2}$ & $\mathrm{~L}_{3}$ & $\mathrm{~L}_{4}$ \\
\hline $7 \mathrm{~mm}$ & $\begin{array}{l}\text { 左 } \\
\text { 右 }\end{array}$ & $\begin{array}{l}0 \\
0\end{array}$ & $\mid \begin{array}{l}0 \\
0\end{array}$ & 10 & $\begin{array}{l}0 \\
0\end{array}$ & 10 & 10 & $\mid \begin{array}{l}0 \\
0\end{array}$ & 10 & $\theta$ & $\begin{array}{l}\theta \\
\theta\end{array}$ & $\begin{array}{l}\theta \\
\theta\end{array}$ & $\begin{array}{l}\theta \\
\theta\end{array}$ & $\begin{array}{l}\theta \\
\theta\end{array}$ & $\theta$ & $\theta$ & $\theta$ & $\theta$ & $\theta$ & & & & & & \\
\hline$\underset{(\mathrm{K})}{6 \mathrm{~mm}}$ & $\begin{array}{l}\text { 左 } \\
\text { 右 }\end{array}$ & & $\begin{array}{l}0 \\
0\end{array}$ & 0 & $\begin{array}{l}0 \\
0\end{array}$ & $\begin{array}{l}0 \\
0\end{array}$ & $\begin{array}{l}0 \\
0\end{array}$ & $\left|\begin{array}{l}0 \\
0\end{array}\right|$ & $\oplus$ & $\oplus$ & $\stackrel{\oplus}{\oplus}$ & $\oplus$ & $\begin{array}{l}\oplus \\
\oplus\end{array}$ & $\begin{array}{l}\oplus \\
\oplus\end{array}$ & $\begin{array}{l}\oplus \\
\oplus\end{array}$ & $\begin{array}{l}\oplus \\
\oplus\end{array}$ & $\oplus$ & $\oplus$ & $\oplus$ & $\oplus$ & $\begin{array}{l}\oplus \\
\oplus\end{array}$ & $\begin{array}{l}\oplus \\
\oplus\end{array}$ & & & \\
\hline$\underset{(\mathrm{a})}{10 \mathrm{~mm}}$ & $\begin{array}{l}\text { 左 } \\
\text { 右 }\end{array}$ & & $\begin{array}{l}0 \\
0\end{array}$ & $\begin{array}{l}0 \\
0\end{array}$ & $\begin{array}{l}0 \\
0\end{array}$ & & 10 & & $\stackrel{\oplus}{\oplus}$ & $\mid \begin{array}{l}\oplus \\
\oplus\end{array}$ & $\stackrel{\oplus}{\oplus}$ & $\oplus$ & $\oplus$ & $\oplus$ & $\begin{array}{l}\oplus \\
\oplus\end{array}$ & $\begin{array}{l}\oplus \\
\oplus\end{array}$ & $\stackrel{\oplus}{\oplus}$ & $\oplus$ & $\oplus$ & $\begin{array}{l}\oplus \\
\oplus\end{array}$ & $\begin{array}{l}\oplus \\
\oplus\end{array}$ & $\oplus$ & $\begin{array}{l}\oplus \\
\oplus\end{array}$ & & \\
\hline$\underset{(\mathrm{K})}{14 \mathrm{~mm}}$ & $\begin{array}{l}\text { 左 } \\
\text { 右 }\end{array}$ & & & & & $\mid \oplus$ & $\oplus$ & & & & $\begin{array}{l}\oplus \\
\oplus\end{array}$ & $\begin{array}{l}\oplus \\
\oplus\end{array}$ & $\oplus$ & $\oplus$ & $(\oplus$ & $\oplus$ & $\begin{array}{l}\oplus \\
\oplus\end{array}$ & $(\oplus$ & $\begin{array}{l}\oplus \\
\oplus\end{array}$ & $\begin{array}{l}\oplus \\
\oplus\end{array}$ & $\begin{array}{l}\oplus \\
\oplus\end{array}$ & $\begin{array}{l}\oplus \\
\oplus\end{array}$ & $\oplus$ & & \\
\hline $13 \mathrm{~mm}$ & $\mid \begin{array}{l}\text { 左 } \\
\text { 右 }\end{array}$ & $\begin{array}{c}\oplus \\
\oplus\end{array}$ & $\begin{array}{l}\oplus \\
\oplus\end{array}$ & & & & & & & & $\begin{array}{l}\oplus \\
\oplus\end{array}$ & $\begin{array}{l}\oplus \\
\oplus\end{array}$ & $\begin{array}{l}\oplus \\
\oplus \\
\end{array}$ & & $\begin{array}{l}\oplus \\
\oplus\end{array}$ & & $\oplus$ & & $\begin{array}{l}\oplus \\
\oplus\end{array}$ & $\oplus$ & $\begin{array}{l}\oplus \\
\oplus\end{array}$ & $\begin{array}{l}\oplus \\
\oplus\end{array}$ & & & \\
\hline $\mathrm{mm}$ & $\begin{array}{l}\text { 左 } \\
\text { 右 }\end{array}$ & $\begin{array}{l}\oplus \\
\oplus\end{array}$ & $\begin{array}{l}\oplus \\
\oplus\end{array}$ & & & & $\begin{array}{l}\oplus \\
\oplus\end{array}$ & $\begin{array}{l}\oplus \\
\oplus\end{array}$ & $\begin{array}{l}\oplus \\
\oplus\end{array}$ & & $\begin{array}{l}\oplus \\
\oplus\end{array}$ & $\begin{array}{l}\oplus \\
\oplus\end{array}$ & $\begin{array}{l}\oplus \\
\oplus\end{array}$ & & $\begin{array}{l}\oplus \\
\oplus\end{array}$ & $\begin{array}{l}\oplus \\
\oplus\end{array}$ & $\begin{array}{l}\oplus \\
\oplus\end{array}$ & $\oplus$ & $\oplus$ & 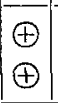 & $\begin{array}{l}\oplus \\
\oplus\end{array}$ & $\oplus$ & $\begin{array}{l}\oplus \\
\oplus\end{array}$ & $\begin{array}{l}\oplus \\
\oplus\end{array}$ & $\begin{array}{l}\oplus \\
\oplus\end{array}$ \\
\hline
\end{tabular}

○細胞性交通枝, 線維性交通枝, ○一部線維性なるも交感神経幹まで達していないるの。

$\mathrm{mm}$ (a) 人胎览飞て，いら゙れ名輪廓の不明䐲な細胞集

団として交感神経幹腹側に，これから少しく離れて現，

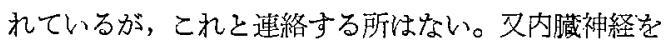
考えさす像も認められない。

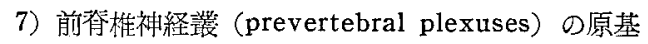
は，著者の $7 \mathrm{~mm}$ 人胎児では存在せず，6 $6 \mathrm{~mm}(\mathrm{~K})$ 人 胎児て大動脈の左右両側飞交感神経幹からのびる䋖胞 集団として考光られるが，未だ細胞の集り方る柾でめ り, 左右のものが大動㟲腹側て連絡する様子も見られ ない。10 mm(a) 人胎児汇到つて大動脈腹側で捙絡す る前脊椎神経業原基として認められるのみならず，こ

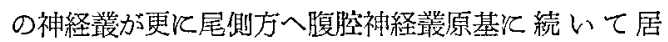
り,これらの神経鋠へは線維の進入がある。前脊椎神 経叢へは交感神経幹加らと；春㗓神経前枝加ら分れる。 吻合枝の分枝の交感神経幹を経過せずにこれに達する。 るのとある。しかるに腹腔神経叢へは前者を欠如し，

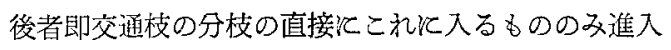
している。即交感神経幹を経過するものよりは, 直接 吻合枝から分れてこれ澾するるの今方が早く線維性 となつている。

8）著者の $14 \mathrm{~mm}(\mathrm{~K})$ 人胎児は Streeter の horizon XVII 飞属せしめて良い発育段階のもので, 交感 神経幹は頭部から仙部门わたり, 線維性の部分がはつ きりし，分節構造が明らか火なつているが，向その線 維束に部分によつてかなり多くの細胞を伴つている。 上神経節, 鎖骨下綰, 下神経節, 前春椎神経鋠及腹腔 神経丵等の構造は，前段階に引続いてや〉明瞭さを増
して来ているが，腹腔神経叢沃於ける神経節形成の様 子は未だ現われず，これは次の段階の $13 \mathrm{~mm}(\mathrm{a}) 人$ 胎児仿於いて初めて明らかである。然し内臟神経原基 は䀣にこの $14 \mathrm{~mm}(\mathrm{~K})$ 例から見完始めて居り, 左側 は $\mathrm{D}_{5}$, 右側は $\mathrm{D}_{4}$ 及 $\mathrm{D}_{5}$ の高さで始まつて腹腔神経

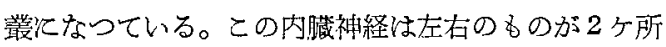
飞於いて互汤合している。副腎原基は前段階よりる 更にその輸廓が明瞭となり，その内側周辺部汇葡質細 胞が見え始めているが，未だ皮望内への進入は見られ ず, 又内藏神経との連絡むない。次の段階の $13 \mathrm{~mm}$ (a) 人胎児で初めて䯣質細胞と内臓神経との肠合が見られ るが，皮質内への進入は $20 \mathrm{~mm}$ 人胎悓で初めて著明 となる。

9）頭部に於ける交感性の神経節及これと附随する 構造が現れ始めるのは，この $14 \mathrm{~mm}(\mathrm{~K})$ 人胎児であ る。頭部の神経節の内, 最もはつきりして現れている すのは颚下゙神経節であつて, 翼口哣神経節及耳神経節 ほ蹯な細胞集団として諗め得ると過ぎず，毛様神経節 は未だこれを認めることが出来ない。

10）鼓荣極㐫て早く，著者の $7 \mathrm{~mm}$ 人胎児て既に 顔面神経から第 1 罶引の方に延びる神経束として現

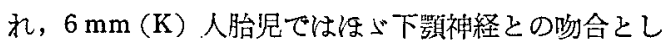
て認められる。10 mm(a)，人胎坚では下顎神経と吻合 はしないが，これと並行して，これょり長く延びて舌 根部外側飞終つている。14 mm (K) 人胎児で初めて 認められる顎下神経節は，鼓甞神経と下顎神経との吻 合部から末梢の方へと，その周囲特にその内側隹る 
細胞集団として現れる。

11)大浅据神経は $10 \mathrm{~mm}$ (a) 人胎归でや〉延び,内 莖動眽て沿つて延びているが，まもなく終り，上顎神 経加らの分枝からも，交感神経幹頭端加与薏心。 $14 \mathrm{~mm}(\mathrm{~K})$ 人胎児ては上神経節頭端加ら出ている内到 動脈神経と合して，未だ瘄跡的な状態の翼口蓋神経節 に終る。Kuntzの $11 \mathrm{~mm}$ 人胎児の所見は，著者の $10 \mathrm{~mm}$ (a) 例近く, や」これるり進んでいる様伈思 われる。

12）鼓室神経杜 $10 \mathrm{~mm}(\mathrm{a})$ 人胎児で極〈疸跡的飞出 現し，舌骨動脈飞接近しているが，直ぐ消失する。 $14 \mathrm{~mm}(\mathrm{~K})$ 人胎児では痕跡的に現れている耳神経節原 基炕小浅岩神経が終つて居り，この耳神経節と下顎神 経との間には吻合が明らかでない。13 mm(a) 人胎児 では鼓室神経柱存在するが，滕神経との肳合も，小浅 岩神経の形成も欠如している。たがし耳神経節原基己 下䫂神経との吻会は存在する。 $20 \mathrm{~mm}$ 人胎照で耳 神経節の輪廓が明瞭となるが，左右乞の状態を異に し，左側では鼓室神経の膝神経節との吻合，小浅岩神 経の形成及その耳神経節への連絡等は $14 \mathrm{~mm}(\mathrm{~K})$ 例 の場合と同様であるが，右側では鼓室神経が膝神経節 と吻合せず，これに接近したま」で終つている。但し 左右共江耳神経節との間の吻合は存在する。Kuntzの 鼓室神経の所見は，7 万至 $8 \mathrm{~mm}$ 人胎児では未失膝 神経節々吻合していないが，9m 人胎児では吻合し ているという。不 Kuntzによると $14 \mathrm{~mm}$ 乃至 $21 \mathrm{~mm}$ 人胎児では耳神経節と翼口蓋神経節との間には, 細胞 条による吻合が存在するといらが, 著者の例では何れ す見られない。

13）毛様神経節原基は頭部交感性神経節の内, 最も 出現遅く, Streeter の horizon XVIII K属する程度 の発育状態の $13 \mathrm{~mm}$ (a) 人胎児で, 初めて去の痕䟢 を認めることが出来る。それ性神経と動眼神経とを 連絡する細胞条として現れ，この紐胞条は更に動眼神 経外側飞接しながら末梢の方へ連続する。この紐胞条 の中に線維は認められない。 $20 \mathrm{~mm}$ 人胎罗でる知長り 雨神経を連絡する紐胞条として見られ，その中若干 の線維を認め得るのみならず, 右側のみ於いて外旋 神経との間に 2 条の線維性の吻合が存在する。この毛 様神経節の所見はほら゙ Kuntz の14 mm, Dixon の $13.6 \mathrm{~mm}$ 人胎児例と時期を等しくする様に思われる。

14）上神経節の頭端加ら線維性の内頸動脈神経及頸 静脈神経が出るのは $14 \mathrm{~mm}(\mathrm{~K})$ 人胎児からで, 前者 は大浅岩神経と吻合し, 後者は舌咽神経の外神経節と
吻合する。合この頸静脈神経はこの胎児では迷走神経 の節状神経節飞接近する枝を出しているが，これとの 吻合は明らかでない。上神経節の尾㑡端から出て大動 脈の周囲の細胞群に終る心趾枝原基は，14 mm(K)人 胎児から見克始め，13 mm(a) 人胎児で尒大体同椂の 状態でするが，これでは迷走神経からの分枝との間に 吻合がある。 $20 \mathrm{~mm}$ 人胎览でねや」これが延びて， His のい 5 Bulbusgeflecht を形成するが, 未だ Vorhofplexus 及 Verbindungsgeflecht を形成する到 S\%h。

15）迷走神経は $7 \mathrm{~mm}$.人胎先て䀝に根の神経節と 節状神経節とに大体分れている。その節状祉経節尾側 端から上㗱頭神経原基分出ている。 $6 \mathrm{~mm}(\mathrm{~K})$ 人胎児 ではその線維性の部分が著明となつて居り，上㫿頭神 経も趈びて居り,本朝も $7 \mathrm{~mm}$ 例では気管分岐の直上, $6 \mathrm{~mm}(\mathrm{~K})$ 例てはその直下に達している。どちらす交 感神経細胞索と節状神経節と近接しているが，雨者の 間には連絡がない。然るに $10 \mathrm{~mm}$ (a) 人胎児では, 交 感神経幹の細胞条が内倶動脈に接して超びている部分 と節状神経節と接近して居り，その尾端との間に雨者 を連絡する1条の細胞条がある。この $10 \mathrm{~mm}(\mathrm{a})$ 例の 迷走神経の本幹胃澾して居り, 途中て上喉頭神経, 反回神経，心臟枝及肺枝等索出す。14 $\mathrm{mm}(\mathrm{K})$ 以上の 人胎忨では，上神経節と節状神経節とが内頸動脈の背 㑡にて一部分面接する状態となるが，この接触は両部 分の鳋含を意味するすのでなく，両者の間に注維性 の吻合が必ず1乃至 2 条存在するすのである。こ」に 注意すべきとは，内䫓動脈との局所的関係であつ て, $13 \mathrm{~mm}$ (a) 人胎览以上では, 内頸動脈の背㑡外側 よりに節状神経節, 背側内側より飞上神経節頭端部, 外側にて節状神経節の腹㑡飞舌咽神経，節状神経節力 ら腹側方に向つて出る上倠頭神経の枝等によつて，内 頸動㟲は完全に神経線維炕つて包团されていること である。

\section{本論文略号説明}

$\mathrm{C}_{1}-\mathrm{C}_{s}$, 第 1-8 影神経節。 $\mathrm{D}_{1}-\mathrm{D}_{12}$, 第 1-12 胸神経 節。 $L_{1}-L_{5}$, 第 1-5 腰神経節。 $S_{1}-S_{5}$, 第 1-5 仙神経 節。III, 動眼神経。 $V$, 三叒神経。 $V_{1}$, 眼神経。 $V_{2}$, 上 顎神経。 $V_{3}$ 下顎神経。VI, 外旋神経。VI, 顔面神経。 UII, 聼平衙神経。 $\mathrm{X}$, 舌咽神経。 $\mathrm{X}$, 迷走神経。 XIG, 副神経神経節。XII, 舌下神経。AH, 舌下神経綰。AS, 鎖骨下綰。CC，総頸動脈。CG，毛様神経節。 $\mathrm{CL}$, 上 㬋頭神経。 COG, 腹腔神経節。 COP, 腹腔神経㦈。 $\mathrm{CR}$, 脊涟神経腹側枝々交感神経幹との間の交通枝。 
$C T$, 鼓菜神経。EC, 外项動脈。 GG, 膝神経節。GP, 胃の迷走神経叢との吻合枝。GSP, 大浅岩神経。HY, 舌骨動脈。IC, 内钼動脈。LSP, 小浅岩神経。NG, 節 状神経節。OG, 耳神経節。 PG, 舌咽神経の外神経節。 $\mathrm{PH}$, 咽頭壁。PPG, 翼曰蓋神経節。SC, 鎖骨下動脈。 $\mathrm{SG}$, 半月状神経節。 $\mathrm{SMG}$, 類下神経節。 $\mathrm{SP}$, 内臓神 経。SPG, 脊㖪神経節。SR, 副腎。SYT, 交感神経幹。 $T Y$, 鼓室神経。VR, 奉檤神経腹側枝。

\section{交献}

1) Schenk u. Birdsall : Mitteil. aus d. embryol. Inst. z. Wien, 2 Hefte, (1878)

2) Onodi, A.D. : Arch. f. mikr. Anat., .26, (1886)

3) His, W. sen. : Arch. f. Anat. u. Physiol. Anat. Abt. Suppl., (1890)

4) His, W. jun. : Anat. Gesellsch. Wien, (1892), Anat. Anz. 7, Erg.-Heft.

5) Kohn, A. : Verh. Anat. Gesellsch. 19 Vers. Anat. Anz. Erg.-Heft., 27, (1905) : Arch. f. mikr. Anat., 70, (1907)

6) Froriep, A. : Medizinisch-naturwiss. Arch., 1, (1908)
7) Kuntz, A. : J. Comp. Neurol and Psychol., 20, (1910)

8) Kuntz, A. : J. Comp. Neurol., 34, (1922)

9) Jones, D.S. : Anat. Rec., 70, (1937)

10) Jones, D.S. : Anat. Rec., 79, (1941)

11) Uchida, S. : Acta Scholae med. Kioto, Vol. X Fasc. I, (1927)

12) Kuntz, A.: J. Comp. Neurol., 96, (1952)

13) Streeter, G.L. : Handbuch d. Entwicklungsgeschichte d. Menschen (Keibel u. Mall, II te Band,)(1911)

14) Streeter, G.L. : Am. J. Anat., 8, (1908)

15) Streeter, G.L. : Am. J. Anat., 4, (1905)

16) Dickie, M.: J. Anat., 48, (1914)

17) Kuntz, A. : J. Comp. Neurol., 32, (1920)

18) Wiemann, H.L. : Anat. Rec., 19, (1920).

19) Hett, J.: Zschr. f. mikr.-anat. Forsch., 3, (1925)

20) Kohno, S. : Zschr. f. Anat. und Entwickl, 77, (1925)

21) His, W. jun. : Arch. f. Anat. und Physiol, Suppl., (1897)

22) Dixon, F.A.: Scient. Transact, of the Royal Dublin Society, VI, Series II, (1896) 